\title{
Terimbilim Odağında ve Çevirmenin Tanıklığında Kuramsal Çeviri ${ }^{1}$
}

\author{
Theoretical Translation in the Focus of Terminology and the Witnessing of Translator
}

Araştırma/Research

\begin{abstract}
Alize CAN RENÇBERLER
Dr., Trakya Üniversitesi, Edebiyat Fakültesi, Mütercim-Tercümanlık Bölümü, alizecan@trakya.edu.tr, ORCID ID: orcid.org/0000-0001-7187-6614
\end{abstract}

\section{ÖZET}

Tüm alanlarda olduğu gibi sosyal bilimlerde kuramsal metin üretiminde ve çevirisinde terim üretimi, çevirisi ve kullanımı araştırmacı ve çevirmen için zorluk oluştururken, terimcelerin çeşitliliği ve yabancı terimler için önerilen farklı terim karşılıkları kuramsal metin çevirilerini güçleştirmektedir. Terim üretimi, çevirisi ve kullanımı kuramsal ve bilimsel söylemlerde terimcelerin oluşturulmasına zemin hazırlamaktadır. Yeni terim üretimi için terimbilimcinin yerli unsurları iyi tanıması, dili yaratıcı şekilde kullanması ve bunları harmanlayacağı terim bilgisine sahip olması bir gerekliliktir. Terimbilimci, gereksinim olduğu durumlarda yeni sözcükler bulabilmeli, terimceyi zenginleştirebilmeli, yabancı dilden ödünç alınan terimler yerine yeni terimler önerebilmelidir. Türkçedeki terim ihtiyacını karşılamak ve özellikle çeviribilim alanında hizmet verecek terim bilgisi ile donatılmış bilinçli çevirmenler yetiştirmek için çalışmalara ihtiyaç duyulmaktadır. Bu çalışmanın amacı, kuramsal metin çevirisinde Türkçe dilbilim, göstergebilim, çeviribilim terimleri sözlüklerine eleştirel yaklaşım geliştirmek ve çevirmenin konumunu ele almaktır. Çalışmanın amacına paralel olarak belirlenen araştırma soruları doğrultusunda örneklem olarak Umberto Eco'nun Interpretation and Overinterpretation (1992) başılılı eseri ile Kemal Atakay tarafından Yorum ve Aşırı Yorum (2011) başlı̆ıyla Türkçeye yapılan çevirisi ele alınmakta, betimleyici yaklaşım ekseninde çevirmen tarafından kullanılan terimler belirlenmekte, dilbilim, göstergebilim, çeviribilim terimleri sözlükleri taranarak terimlerin karşılıkları Öztürk Kasar'ın

${ }^{1}$ Bu çalışmanın bir bölümü 3-5 Mayıs 2018 tarihinde Alanya Alaaddin Keykubat Üniversitesi'nde düzenlenen 4. Asos Congress - Uluslararası Filoloji Sempozyumu'nda “Umberto Eco'nun Interpretation and Overinterpretation Başlıklı Eserinin ve Türkçe Çevirisinin Terim Bağlamında İncelenmesi: Sorunlar ve Terim Önerileri” başlığı ile sözlü bildiri olarak sunulmuş ve özeti sempozyum özet kitapçığında yayımlanmıştır. 
oluşturduğu Terimsel Gereksinim ve Yaratıcılık Düzeyleri Şemasına göre listelenmekte ve çevirmen Kemal Atakay'ın çeviri süreci ve terim çevirisi üzerine görüşlerine yer verilmektedir. Sonuç olarak, incelenen özgün ve çeviri metinlerden hareketle dilbilim, göstergebilim, çeviribilim terimleri sözlüklerinde bazı boşluklar olduğu ve kullanımda olan terimlerin bir kısmının standart halde olmadığı anlaşılmaktadır. Bununla birlikte, çeviri sürecine dair çevirmenin görüşlerine ve karşılı̆̆ı olmayan terimleri dilimize aktarırken izlediği stratejilere yer vermenin çevirmen adaylarına kuramsal metin çevirisi kapsamında terim aktarımına ilişkin yöntemler sunduğu sonucuna da varılmaktadır.

Anahtar Sözcükler: terim, terim çevirisi, kuramsal çeviri

\begin{abstract}
As in all fields, using, generating and translating the terms for producing and translating theoretical texts in social sciences is a challenge for researchers and translators. The variety of terms and frequently used equivalent words can complicate the translation of theoretical texts. Generating, translating and using these terms pave the way for constituting glossaries. Translators should be well acquainted with native components, and their terminologies, to be able to use them in a creative and inspiring way. A terminologist, whenever necessary, should generate new words, enrich these glossaries and propose new terms instead of those that are borrowed from foreign languages. Academic studies are required to fulfil terminological needs in Turkish and train competent translators who are equipped with the necessary terminological knowledge in translation studies. This study aims to develop a critical view of the dictionaries of linguistics, semiotics, translation studies, literary terms and to discuss the position of the translator in the translation of theoretical texts. In line with the research questions defined in parallel with the aim of the study, the terms in Interpretation and Overinterpretation by Umberto Eco (1992) and its Turkish translation Yorum ve Aşırı Yorum by Kemal Atakay (2011) are compared and contrasted and the terms used and proposed by the translator are listed in the context of the descriptive approach. For comparing the terms, several resources are used, including dictionaries of linguistics, semiotics, translation studies and literary terms. The dictionaries of linguistics, semiotics, translation studies and literary terms are examined according to the Schema of Levels of Terminological Needs and Creativity proposed by Öztürk Kasar and the translator's views of the translation process and term translation are presented. In conclusion, it is deduced that there are some gaps in the dictionaries of linguistics, semiotics, translation studies and literary terms and some of the terms in use are not in the standard state. Besides, it is inferred that including the opinions of the translator on the translation process and the strategies developed while translating the terms, which do not correspond to target language, offer translator candidates methods of translating terms within the context of theoretical text translation.
\end{abstract}

Keywords: term, translation of terms, theoretical translation

\title{
1. Giriş
}

Sağıık bilimleri, sosyal bilimler, fen bilimleri ve sanat alanında çalışma yapan, kuramsal ve bilimsel metin üreten ve okuyan her disiplinden araştırmacının ihtiyaç duyduğu öncelikli temel öğenin terim olduğu düşünülebilir. Bu başlık altında öncelikle, terimbilime 
ve terime, terimin özelliklerine, terim oluşturmada uygulanan yöntemlere, terimbilimin çeviribilimle ilişkisine ve Türkiye'de terim çalışmalarına değinilecektir.

Terimlerin düzenli şekilde incelenmesi ile ilgilenen terimbilim ise Uluslararası Terimbilim Birliği'ne göre [International Association of Terminology] şu şekilde ele alınmaktadır:

Terimbilim, uzmanlık bilgisi gerektiren özel alanlarda insanlararası iletişim için gerekli olan simgelerin ve dilsel göstergelerin araştırılması ve uygulanması ile ilgilenen bir bilim dalıdır. Her şeyden önce dilbilimle ilintilidir -'dilbilim' - burada en geniş anlamıyla ele alınmalıdır - ancak, çoğunlukla anlambilim ve edimbilim gibi dalları ilgilendirmektedir. Disiplinlerarası bir bilim dalı olarak isimlendirilmesinin nedeni göstergebilim, bilgi kuramı, sınıflandırma gibi bilim dallarından kavramlar ve yöntemler ödünç almasından ve uygulamasından kaynaklanmaktadır. (IAT, 1982)

Étude Lexicologique d'un Champ Notionnel [Bir Kavram Alanının Sözlükbilimsel Incelenişi] adlı doktora tezi ve Structure Fondamentale du Vocabulaire Social et Politique en France de 1815 à 1830 [1815'ten 1830'a değin Fransa'da Siyasal ve Toplumsal Sözlüğün Temel Yapısı] başlıklı doçentlik tezinin yanı sıra ekibiyle birlikte hazırladığı Dilbilim ve Dilbilgisi Terimleri Sözlüğü makaleleri ile terimbilim alanında Türkiye'de başı çeken araştırmacı Berke Vardar'ın Terimsel Etkinlik ve Terimbilim (1980, s. 385) başlıklı çalışmasına göre, bilim ve teknolojinin hızla ilerlemesi ve buna koşut olarak iletişim ihtiyaçlarının çoğalmasıyla birlikte artan terim ihtiyacı ile dildeki terimsel açığı kapatmak için düşünülen ve uygulanan çözümler terimbilim olarak isimlendirilen yeni bir alanın doğmasına zemin hazırlamıştır. Vardar, aynı çalışmasında terimbilimin, özellikle sözlükbilimden destek aldığına vurgu yaparak birçok yönüyle uygulamalı dilbilim dalı olduğunun altını çizer; terimleri inceleyen ve terimler üzerine yapılan çalışmalara yön veren ilkeleri belirleyen sözlükbilimin yanında diğer uzmanlık alanları ve disiplinlerle de iç içe olması nedeniyle disiplinlerarası bir niteliğinin olduğunu belirtir. Vardar'ın

(...) çeşitli nesne ve kavramlara ilişkin adlandırma eyleminin mantıksal görünümleri, toplumsal bildirişim çevrimindeki yeri, dillerarası ilişkiler, çeviri, belgeleme, bilgi-işlem vb. konularla bağıntıları terimbilimin ne denli geniş kapsamlı bir yaklaşım türü içermesi gerektiğini ortaya koymaktadır. (1980, s. 386)

sözlerinden terimbilimin diğer uzmanlık alanlarında iletişimi sağlayan kilit öğe olduğu kanısına varılabilir.

Sunulan tanımdan da anlaşılacağı üzere, terimbilimin hem bir araştırma hem de uygulama alanı olduğu vurgulanmış, dilbilimle iç içe olduğuna değinilmiş ve diğer bilim dallarından yöntemsel ve kavramsal açıdan yararlandığı için disiplinlerarasılık özelliği gösterdiği vurgulanmıştır.

Türk Dil Kurumu Türkçe Sözlük'te terim, "bir bilim, sanat, meslek dalıyla veya bir konu ile ilgili özel ve belirli bir kavramı karşılayan kelime, ıstılah" şeklinde tanımlanmaktadır (1988, s. 1458). Burcu Illkay Karaman'a göre, terimler "kavramlar 
hakkında konuşulurken kullanılan sembollerdir (2017, s. 93). Karaman, terimlerin belli bir kullanım alanı için anlamları açık bir biçimde tanımlandığını ve bağlamlara göre anlam değiştirmediklerini ifade etmektedir (s. 93). Benzer şekilde Asalet Erten da terimlerin bolca kullanıldığı bilimsel ve teknik metinlerin çoğunlukla düz anlama sahip olduğunu belirtmektedir (1993, s. 315). Hamza Zülfikar da terimlerin çeşitli bilim dallarının, sanat ve meslek kollarının özel kelimeleri olarak tanımlandığını, anlamlarının dar ve sınırlı olduğunu, bilim dallarının, sanat ve meslek kolları mensupları arasında kısa yoldan anlaşmayı sağlayan sözler olduğunu belirtmektedir (2011, s. 20). Tanımlardan hareketle terimin, belirli bir uzmanlık alanında, özel anlam taşıyan kavramları karşılayan sözcükler olduğu anlaşılmaktadır.

Zülfikar, çalışmasında terimlerin özelliklerini şu şekilde sıralamıştır :

1. Terimler bir bilimsel kavrama tek karşılık sunarlar.

2. Terimlerin anlamları sabittir ve cümle içinde olsa bile değişik anlamlarda kullanılmazlar.

3. Terimler halkın söz varlığında yer almaz ama halk ağzında kullanılıp da sonradan terim özelliği kazanmış kelimeler vardır.

4. Gündelik dilde sık geçen bir kelimenin terim olarak kullanılması söz konusu olabilir. Dolayısı ile bir kelimenin temel, yan ve mecaz anlamları dışında terim niteliğinde olan anlamları bulunabilir.

5. Kimi terimlerin de anlamları iyice daralmış olabilir ve sözlüklerde sadece bir terim olarak yer alabilirler.

6. Terimler kavramları açık ve net bir şekilde karşılarlar. Bu bağlamda terimin milli olmasının (Türkçe terimlerin Türkçe kök ve eklerden yaratılması) yararları vardır.

7. Terimler genel dilin kelimelerinden keskin çizgilerle ayrılamaz ancak tanımı, kullanımı, aldığı yapım ekleriyle bir ölçüde dilin diğer kelimelerinden ayırt edilebilirler. (2011, ss. 20-3)

Karaman ise terimlerin niteliklerini şu şekilde sunar :

1. Saydamlık: Terimler, var olan terim düzenlerine uyum sağlayacak şekilde adlandırılırlar.

2. Salkımlıık (Düzenlilik/Sistematiklik): Terimler kavram düzenini yansıtır biçimde oluşturulmuşlardır.

3. Tutarlıık (Eşanlamsızlık): Bir terim oluşturulduğunda kullanılagelen eşanlamlıları kullanımdışı bırakılır.

4. Bağlamsızlık/Biriciklik (Tekanlamlılık ve Tekadlılık): Terimler genelde yananlamsız olma özelliği gözönünde bulundurularak oluşturulmaya çalışılmıltır.

5. Elverişlilik/Ekonomiklik: Tutunabilmeleri için terimler akılda kalabilecek biçimde oluşturulmuştur.

6. Yerellik: türetilebilirlik hedeflenerek dilde varolan kaynaklardan faydalanılmıştır.

7. Güncellik: terimlerin güncel olmaları için gözden geçirilmesi gereklidir. (2017, ss. 49-52) 
Roman Jakobson, her bilişsel deneyimin bir başka dile çevrilebilir ve düzenlenebilir olduğunu dile getirmiştir, yetersiz kalındığı durumlarda ise terimlerin aktarmalarla, öyküntülerle, yeni sözcüklerle, anlam kaydırmalarıyla ve dolaşık anlatımla değiştirilebilir olduğunu vurgulamıştır (2000, s. 115). Terim yapma yolları ile ilgili olarak benzer şekilde Zülfikar da kelimelere eklenen ekler ve köklerin yanı sıra kelime birleştirme, tamlamalar kurma, kelimenin türlerini değiştirme, genel dilden ve halk ağzından kelime aktarma gibi yöntemlerin başvurulabilir olduğunu belirtmiştir (ss. 149150). Karaman da çalışmasında terim oluştururken kullanılan yöntemleri yeniden anlamlandırma, takılama (türetme), birleştirme (birleşik terim), örnekseme, birebir çeviri ve uluslararasılaştırma olarak sıralamaktadır (ss. 47-8).

Mustafa Durak'ın (2005, s. 11) Vardar'dan aktardığı üzere, terimlerin ortaya çıkışı ile genel kullanımda olan yeni sözcükler gibi terimlerin de esasında dilin kendisinden alıntılar yaparak ve anlamda özelleşmeye bağı yaratımlar çerçevesindeki ögelerin dizimsel bağlanışına dayalı üretilen birimler olduğunu belirtir ve bu durumu, (kimyada) arı, (geometride) doğru, (dilbilgisinde) ek, (fizikte) sıvı gibi terimleri örnek vererek somutlaştırır. Vardar'ın, bilimsel söylemlerde yabancı terimlerin yerine yenilerinin önerilmesini, diğer bir deyişle yerli ögelere dayalı terimsel yenilenmeyi savunduğu açıkça ortadadır. Terim ihtiyacına zemin hazırlayan bir diğer nokta ise genel dilin sözlük kesiminde karşılaşılan güçlü değişimdir (Vardar, 1980, s. 386). Dilin her döneminde değişimler olduğunun altını çizen Vardar, bu olgunun yaratıcılık şeklinde isimlendirildiğini belirtir. Buradan hareketle, günlük konuşma dilinde ortaya çıkan yeni sözcüklerin, bilim dallarında ve uzmanlık alanlarında kullanılan terimlere etki ettiği, zamanla değişen dil kullanımlarının etkisiyle, yeni terimlere ihtiyaç duyulduğu anlamı çıkarılabilir.

Terimbilimin araştırma alanına giren bu etkinlikler beraberinde bir takım işlemler de gerektirir. Vardar, aynı çalışmasında (1980, ss. 387-8) Robert Dubuc'tan (1977) aktardığı üzere dört temel işlemden oluşan bir yöntemsel çerçeveden bahseder: belirleme, çözümleme, yaratım ve ölçünleme. Belirleme, belli bir uzmanlık dalına ilişkin bir metin ya da somut bir bildirişim durumunu ele alan terimbilimcinin, üstüne eğildiği alana özgü öğeleri saptaması" işlemidir. Çözümleme, "bağlam içinde ele alınan öğelerin kavramsal niteliğini ya da içeriğini ortaya koyma" işlemidir. Bu işlemde, dilbilimcilerin "anlambirimcik çözümlemesi" olarak adlandırdıkları işlem gerçekleşir. "Belirleme işlemi birbirini izleyen öğeler düzleminde gerçekleşirken, çözümleme işlemi birbirinin yerini alan öğelerin oluşturduğu dizge çerçevesinde en küçük anlamsal oluşturucuların saptanmasını gerektirir" (1977, s. 270). Yaratım işleminde ise, "terimsel etkinlikte bulunan uzman dizgenin belli bir noktasında herhangi bir boşlukla karşılaştığında, bir başka deyişle gereksinme olduğunda yeni sözcük yaratımı kesin bir zorunluk olarak ortaya çıkar" (1977, s. 271). Ölçünleme olarak adlandırılan ve terimbilimin toplumsal yanını oluşturan son işlem basamağında ise, "terimbilimci belli bir uzmanlık alanında özdeş kullanımları benimsetme, bu kullanımlara geçerlik ve yaygınlık kazandırma eylemini" üstlenmektedir (1977, s. 271). Bu işlem, yön verici bir etkinlik olduğu kadar 
kullanıcıların tepkilerinden de etkilenen ve gereksinimlere uygun öneriler getirdiği sürece etki alanını genişleten bir olgudur.

Ülkemizde 1932 yılında Türk Dil Kurumu'nun kurulmasıyla bilinçli şekilde terim çalışmaları yapılmaya başlanmış ve takip eden yıllarda Türk Dil Kurumu terim yapan ve yayan bir merkez konumuna gelmiştir (Zülfikar, 2011, ss. 8-9). Terim üretme ve yayma konusunda başka kurumların da rolü olmuş, bunlar arasında kimi yayınevleri terim sözlükleri yayımlamıştır (Zülfikar, 2011, s. 11). Terim çalışmalarına proje, sempozyum, kurultay ve akademik derslerle katkı sağlayan üniversiteleri de bu noktada anmak gereklidir. Bunlardan ilki Yıldız Teknik Üniversitesi'nin disiplinlerarası düzeyde hizmet vermeyi amaçlayan ve Türkçe terimlerin ulusal düzeyde yaygınlaşmasını sağlamaya hizmet verecek Türkçe Terim ve Sözcükdizini olarak adlandırdığı projedir (Karaman, 2017, s. 77). Benzer şekilde Hacettepe Üniversitesi'nin de yürütmüş olduğu Terim Uzmanlığı Eğitimi, TERMTURK-Kültürlerarası Diyalog ve Özel Illetişim Iç̧in Terminoloji ve Almanca, Ingilizce ve Türkçe Otomotiv Terimleri Bütüncesinde Çeviri Amaçlı Kavramlaştırma ve Adlandırma Çalışması gibi projeler terim çalışmalarına katkı sağlamaktadır³. 20-21 Ekim 2011 tarihlerinde Kırıkkale Üniversitesi Fransızca MütercimTercümanlık Anabilim Dalı tarafından düzenlenen I. Uluslararası Çeviribilim ve Terimbilim Kurultayı da terim çalışmalarına katkı sağlayan bir bilimsel etkinliktir. Bunlara ek olarak İstanbul Üniversitesi, Ege Üniversitesi, Trakya Üniversitesi, Yıldız Teknik Üniversitesi ve Hacettepe Üniversitesi'nde Mütercim Tercümanlık ve Çeviribilim Bölümlerinde terimbilim ve özel alan çevirisine yönelik terim bilgisiyle donatılmış çevirmenler yetiştirmeye yönelik lisans ve lisansüstü düzeyde dersler ve projeler yürütülmektedir.

Çok dilli terimbilimsel eylemlerin kuramsal çeviriyi desteklemesi çevirmenlerin sorumluluğunun artması anlamına gelmektedir. Bu bağlamda, çevirmenlerin sadece iki dil ve kültür hakkında bilgi sahibi olmasının yanında terimler hakkında da yetkinlik kazanması gerekmektedir. Nevzat Gözaydın bu konu ile ilgili olarak 7-9 Mart 2008'de Antalya'da düzenlenen Türkçe ve Çeviri Sorunları Çalıştayı'nda çevirmenlerin uzmanlık alan bilgisi gerektiren terimleri çok iyi bilmelerinin gerekliliğine değinmiş $(2008$, s. 19) ve karşılaşılabilecek sorunların çözümü için çevirmenlerin yanı sıra sosyolog, antropolog, tarihçi, coğrafyacı gibi diğer disiplinler üzerine çalışan araştırmacıları işbirliğine davet etmiştir (s. 23). Ayfer Altay da Initiating a terminology policy, the case of Turkey: TermTurk Project başlıklı çalışmasında Türkiye'nin Avrupa Birliği'ne katılma sürecinde çeviri eylemlerinin arttığına ve yapılan çevirilerin çoğunlukla terim bilgisi gerektiren teknik çeviriler olduğuna değinmiş, bu metinlerin çevrilmesinde karşılaşılan sorunların terimbilim veri tabanları yardımıyla ortadan kaldırılabileceğini öne sürmüştür (2011, s. 151). Altay'ın Cihan Alan ve Ender Ateşman ile yürüttüğü Towards a Terminology Centre: Awareness, Project, Outcome (2011) başlıklı çalışma da terim birliğinin önemini

\footnotetext{
2 http://www.termturk.org/objectives.php Erişim Tarihi [19.06.2020]

${ }^{3}$ Hacettepe Üniversitesi, Mütercim Tercümanlık Bölümü, Projeler http://www.mtb.hacettepe.edu.tr/projeler.php Erişim Tarihi [20.06.2020]
} 
vurgulayan ve bu amaçla yürütülen eğitimleri ve faaliyetleri konu edindikleri diğer önemli bir kaynaktır.

Bruno de Bessé, Terim Sorunları başlıklı çalışmasında, "terim çalışmasının amacının dilsel engelleri aşmak, yazılı ya da sözlü çalışan çevirmenleri etkin araçla donatmak" olduğunu vurgulamaktadır. Araştırmacı, terim sorunlarına yönelik olarak, farklı dillerden halklar arasında alış-verişin sadece terim araştırmalarına dayalı çeviri çalışmalarına bağlı olduğunu belirtmektedir $(2005$, s. 28).

Bu çağrıya paralel olarak Yıldız Teknik Üniversitesi Diller ve Kültürlerarası Çeviribilim Doktora Programı bünyesinde Prof. Dr. Sündüz Öztürk Kasar, gerek vermiş olduğu lisansüstü derslerle ve bu derslerde yürütülen kuramsal metin çevirisi projeleriyle, gerekse terim çevirisine dair yapmış olduğu akademik araştırma ve incelemelerle terim araştırmalarına dayalı çeviri çalışmalarını sürdürmektedir. Öztürk Kasar'ın Algirdas Julien Greimas'ın sémantique structurale adlı yapıtını Türkçeye nasıl çevirmeli? (2017, ss. 308-316) adlı eseri sosyal bilimlerde kuramsal metin çevirisini konu edinen, adı geçen eserinin terimcesini oluşturma deneyimini paylaştığı, Türkiye'de göstergebilim terimcesinin oluşumu için önerilerde bulunduğu ve eserin muhtemel çevirmeninin profilini çizdiği bir araştırmadır.

Öztürk Kasar yönetiminde "Sosyal Bilimlerde Kuram Çevirisi" adlı doktora dersi dahilinde ise dilimizde terim gereksinimlerini gidermek ve terimbilimden yararlanarak çeviribilim alanına katkı sağlayacak çevirmenler yetiştirmek hedeflenmektedir. Bunun yanı sıra, Öztürk Kasar'ın Didem Tuna ile birlikte oluşturduğu, Sosyal Bilimler Alanında Terimcelerin Çevrilmesi ve Türkçe Terim Üretimi isimli çalışmada sunulduğu üzere, kuramsal metin çevirisinde var olan gereksinim düzeyleri ve bu gereksinimleri karşılamak için başvurulacak yaratıcılık düzeylerini belirten Terimsel Gereksinim ve Yaratıcılık Düzeyleri Şeması (Öztürk Kasar \& Tuna, 2017, ss. 433-5) terimbilim alanına sağlanan bir katkı olarak düşünülebilir.

Bu çalışmada da terimlerin taranması ve gerekli durumlarda yeni terim önerileri gereksiniminin belirlenmesi Öztürk Kasar'ın oluşturduğu sınıflandırma doğrultusunda yapılacağı için Terimsel Gereksinim ve Yaratıcılık Düzeyleri Şeması "Veri Çözümleme Araçları" alt başlığında detaylı olarak ele alınacaktır.

\section{2. Çalışmanın Yöntemi}

Bu bölümde öncelikle çalışmanın amacına değinilecek olup, belirlenen amaçlar doğrultusunda araştırma soruları belirlenecektir. Takip eden alt başlıklarda araştırma yöntemine, veri toplama ve veri çözümleme araçlarına yer verilecektir.

\section{1 Çalışmanın Amacı}

Kuramsal metinler, özel alan bilgisi gerektiren terimlerle donatılmış, yeni isimlendirmelerin ve kavramların dolaşıma girdiği, hem okurun hem de çevirmenin yeni terim ve kavramlarla karşılaşabildiği bir alandır. Kavramların doğru algılanması ve hedef 
okurun üzerinde aynı etkiyi yaratması ve aynı bilgiyi aktarabilmesi terim birliğinin sağlanmasıyla mümkündür. Bu durumda, kullanımda olan sözlük ve terimcelerin bu gereksinimi karşılaması ve karşılığı olmayan terimlere de çevirmenlerin uygun karşılıklar bulması beklenmektedir. Buradan hareketle, çalışmanın amacı kuramsal metin çevirisinde dilbilim, göstergebilim, çeviribilim terimleri sözlüklerinin terim gereksinimlerine ne ölçüde cevap verdiğini incelemek ve kuramsal metin çevirisi yapan çevirmenin görüş ve tecrübelerine yer vererek çeviri sürecini somutlaştırmak olarak belirlenmiştir.

\section{2 Çalışmanın Araştırma Soruları}

Çalışmanın yukarıda sunulan amaçları doğrultusunda araştırma soruları sözlükler ve çevirmen özelinde belirlenmiştir. Buna göre,

1. Sözlüklere yönelik olarak

a. Kullanımda olan dilbilim, göstergebilim, çeviribilim terimleri sözlükleri kuramsal çevirinin gereksinimlerine yanıt veriyor mu?

2. Çevirmene yönelik olarak

a. Çevirmen, çeviri süreci öncesinde metin ile ilgili olarak herhangi bir hazırlık yapıyor mu?

b. Çevirmen, dilimizde henüz karşılığı olmayan terimleri Türkçeye aktarırken hangi yöntemlere başvuruyor?

c. Çevirmenin, dilbilim, göstergebilim, çeviribilim terimleri sözlüklerinde karşılığı olup kullanımlarına ya da bu terimlere alternatif olarak daha güncel tınısı olan yeni terim önerisine karşı tutumu nedir?

soruları, çalışmanın araştırma soruları olarak belirlenmiştir.

\subsection{Araştırma Yöntemi}

Çalışmanın amacı, kullanımda olan sözlüklerin kuramsal çeviriye olan katkısını ve çevirmenin kuramsal çeviri üzerine düşüncelerini betimleyici yaklaşımla ortaya koymak olduğu için çalışmanın araştırma yöntemi durum çalışması ${ }^{4}$ (case study) olarak belirlenmiştir.

\subsection{Veri Toplama Araçları}

Durum çalışması araştırma yöntemine ve çalışmanın amacına uygun olarak veri toplama araçları doküman incelemesi ve görüşme olarak belirlenmiş; bu bağlamda incelenecek dokümanlar özgün ve çeviri metin olarak saptanmıştır. Kullanılan özgün metin Umberto Eco'nun İngilizce kaleme aldığı Interpretation and Overinterpretation (1992) başlıklı eseri ile Türkçeye Kemal Atakay tarafından çeviri metin olarak aktarılan Yorum ve Aşırı Yorum

${ }^{4}$ Durum çalışması ile ilgili detaylı bilgi için bkz. Berg, 2001; Yıldırım \& Şimşek, 2013; Berg \& Lune, 2015; Duff, 2007. 
(2011) adlı yapıttır. Beş araştırmacının konuşma metinlerinden oluşan özgün metin ile çevirisinde ele alınan terimler sadece Umberto Eco'nun konuşma metinleri ile sınırlı tutulmuştur. Çalışmanın örneklemi olarak Interpretation and Overinterpretation başlıklı eserin seçilmesinin sebebi ise, dilbilim, göstergebilim, çeviribilim terimleri sözlüklerinin tümüne başvurmak için uygun bir metin olmasıdır.

Çalışma kapsamında başvurulan diğer bir veri toplama aracı ise çevirmenle yapılan görüşmedir. Çevirmen Kemal Atakay'la 21.04.2018-25.04.2018 tarihleri arasında elektronik posta aracılığı ile görüşülmüş, çalışmanın amacı ve kapsamı hakkında bilgi verilmiş ve çevirmene kuram çevirisine yönelik şahsi fikir ve tecrübeleri hakkında sorular yöneltilmiştir.

\subsection{Veri Çözümleme Araçları}

Çalışmada sözlükler ve Terimsel Gereksinim ve Yaratıcılık Düzeyleri Şeması Şeması (2017, s. 418) veri çözümleme araçları olarak belirlenmiş, detaylı bilgi aşağıda sunulmuştur.

\subsubsection{Sözlükler}

$\mathrm{Bu}$ çalışmada, beş araştırmacının konuşma metinlerinden oluşan özgün metin Interpretation and Overinterpretation ile çeviri metin Yorum ve Aşırı Yorum'da ele alınan terimler sadece Umberto Eco'nun konuşma metinleri ile sınırlı tutulmuştur. Özgün ve çeviri metinlerde karşılaştırmalı şekilde incelenen terimler alfabetik sıra ile listelenmiştir. Özgün yapıtta ve Türkçe çevirisinde yer alan terimlerin Türkçe karşılıklarını bulmak için çeviribilim, göstergebilim, dilbilim terimleri sözlüklerinden yararlanılmıştır. Çalışmada kullanılan sözlükler:

- Açıklamalı Dilbilim Terimleri Sözlüğü (Vardar, Güz, Huber, Senemoğlu \& Öztokat, 2007),

- Dilbilim Sözlüğü (İmer, Kocaman \& Özsoy, 2013),

- Göstergebilim, Dilbilim ve Çeviribilim Terimleri Sözlüğü (Rifat, Rifat, Koş \& Tekgül, 2010),

- Açıklamalı Göstergebilim Sözlüğü (Rifat, 2018),

- Çeviri Terimleri Sözlüğü (Bengi-Öner, 2001),

- Açıklamalı Çeviri Terimleri Sözlüğü (Boztaş, Okyayuz Yener, 2005),

- Kuramlar Işığında Açıklamalı Çeviribilim Terimcesi (Berk, 2005).

Bu sözlüklerde karşılığı bulunmayan terimleri değerlendirmek için çevirmenin önerdiği terimler dikkate alınarak ve Türkçe-Ingilizce/Ingilizce-Türkçe ${ }^{5}$ sözlüklerden ve Türk Dil Kurumu'nun Büyük Türkçe Sözlüğ̈̈'nden ${ }^{6}$ yararlanılacaktır.

\subsubsection{Terimsel Gereksinim ve Yaratıcılık Düzeyleri Şeması}

\footnotetext{
${ }^{5}$ Cambridge Dictionary English-Turkish Dictionary. http://dictionary.cambridge.org/dictionary/turkish Erişim Tarihi [23.09.2019]

Oxford Dictionaries. https://www.oxforddictionaries.com/ Erişim tarihi [23.09.2019]

Online Dictionaries by bab.la - Turkish-English/English-Turkish. https://en.bab.la Erişim tarihi [23.09.2019]

${ }^{6}$ Türk Dil Kurumu - Büyük Türkçe Sözlük. www.tdk.gov.tr Erişim tarihi [23.09.2019]
} 
Terimsel Gereksinim ve Yaratıcılık Düzeyleri Şeması, Öztürk Kasar’ın önceki bölümde adı geçen doktora dersi kapsamında sunulmuş projelerin gözlemlerinden oluşturduğu dört aşamalı bir sınıflamadır. Bu sınıflamaya göre Öztürk Kasar, sıfır gereksinim olarak adlandırdığı kategoride "yerleşmiş ve standartlaşmış Türkçe karşılıkları bulunan terimlere ilişkin seçim yapma ya da karşılıklar arama gereksinimi" olduğunu belirtir (2017, s. 434). Öztürk Kasar bu sınıfta, équivalence/equivalence (eşdeğerlik), signifiantsignifié/signifier-signifiant (gösteren-gösterilen) ve adaptation/adaptation (uyarlama) örneklerini gösterir. Bu durumda, yeni terim oluşturmak için ilave bir çaba göstermeye gereksinim yoktur. Şemanın ikinci basamağını birincil gereksinim şeklinde adlandırılan kategori oluşturur. Bu grupta, "birden fazla karşılığı bulunan ve birbirleriyle yarışan terimler arasından en uygun olanını seçmek söz konusu olduğunda duyulan gereksinim düzeyidir" (2017, s. 434). Bu noktada da çaba gerektirecek bir gereksinim söz konusu değildir ancak bir standart oluşturmak amacıyla var olan terimlerden birini seçerek "tamamlayıcı bir yaratıcı edim ortaya koymak gerekmektedir" (2017, s. 434). Örnek olarak ise, Fransızca stylistique ve Ingilizce stylistics terimlerinin dilimizde üslupbilim, biçembilim, anlatımbilim ve deyişbilim olarak dört karşılığının bulunduğu ve sıralanan terimler arasında deyişbilimin daha çok kabul gördüğü vurgulanmaktadır. Ikincil gereksinim olarak şemanın üçüncü basamağını oluşturan sınıf bir terimin bir veya daha fazla karşılığının olmasına rağmen sunulan karşılıkların uygun görülmeyip yeni bir terim üretme gereksiniminin olması durumudur (2017, s. 434). Bu bağlamda, çevirmen etkin rol üstlenir. Öztürk Kasar, bu kategoriye örnek olarak Fransızca surinterprétation ve İngilizce overinterpretation terimleri için önerilen fazla çeviri ve artık çeviri terimlerinin anlamı tam yansıtmadıkları için uygun olmadıklarını ve Yorum ve Aşırı Yorum eserinden esinlenerek aşırı çeviri terimini önerdiğini belirtmiştir (2017, s. 435). Şemanın son basamağını oluşturan tam gereksinim basamağı, yeni bir terim oluşturmanın kaçınılmaz olduğu durumdur. Bu durumda, terimin hiçbir karşılığı yoktur ve çevirmen yaratıcılığına ve artalan terim bilgisine başvurarak kavramsal anlam içeriğinden hareketle yeni bir terim önermek zorundadır (2017, s. 435). Bu basamak için ambivalence terimi ve çelişik sesteşlik Türkçe karşılığı önerilmektedir. Bu terim önerisinde, "ambivalence sözcüğünün içinde barındırdığı çelişiklik, karmaşıklık ve kararsızlık kavramlarından esinlenilmiş ve terimin tanımından yararlanılmıştır" (2017, s. 435).

Aşağıdaki tablo, terimler için duyulan gereksinim düzeyleri ile bu düzeylerin gereksinimlerinin giderilmesi için ihtiyaç duyulan yaratıcılık düzeylerini belirtmektedir. $\mathrm{Bu}$ çalışma kapsamında özgün ve çeviri metinde taranan terimler bu şemaya göre sınıflandırılacaktır.

Tablo 1: Sündüz Öztürk Kasar’ın Terimsel Gereksinim ve Yaratıcılık Düzeyleri Şeması (2017, s. 418)

\begin{tabular}{|l|l|l|}
\hline & Terimsel Gereksinim Düzeyleri & Yaratıcılık Düzeyi \\
\hline 1. & Sıfır Gereksinim & Sıfır Yaratıcılık \\
\hline 2. & Birincil Gereksinim & Tamamlayıcı Yaratıcılık \\
\hline 3. & İkincil Gereksinim & Gerekli Yaratıcılık \\
\hline 4. & Tam Gereksinim & Zorunlu Yaratıcılık \\
\hline
\end{tabular}




\section{Bulgular ve Yorum}

Bu başlık altında yazar ve özgün metin, çevirmen, çeviri metin, çevirmenin çeviri süreci ve kuram çevirisi üzerine görüşleri ve terim incelemesine yer verilecektir.

\subsection{Yazar ve Özgün Metin}

5 Ocak 1932 tarihinde İtalya'nın Piedmont bölgesinde Alessandria şehrinde dünyaya gelen Umberto Eco, Torino Üniversitesinde Ortaçağ Felsefesi ve Edebiyatı üzerine uzmanlaşmıştır. Lisans çalışmasının ardından yüksek lisans ve doktora çalışmalarını Aziz Tommaso d'Aquino üzerine gerçekleştirmiştir. Thomasçııı akımı ve bu akımın estetik yaklaşımı üzerine derin incelemelerde bulunmuştur. Eleştirmen, yazar, edebiyatçı, ortaçağ estetikçisi, tarihçi, filozof, göstergebilimci gibi çok katmanlı bir akademik kimliğe sahip olan Umberto Eco, Bologna Üniversitesinde göstergebilim kürsüsünde görev yapmış, ardından Harvard, Cambridge ve Oxford gibi dünyanın önde gelen üniversitelerinde davetli olarak seminerler vermiştir. Ortaçağ tarihi, estetik ve göstergebilim üzerine kaleme aldığı birçok kuramsal kitap ve akademik yayının yanı sıra Gülün Adı, Foucault Sarkacı, Baudolino ve Önceki Günün Adası gibi birçok dile çevrilmiş ve hemen her dilden okura ulaşmış romanları da bulunmaktadır. 19 Şubat 2016 tarihinde Milan'da yaşadığı evde pankreas kanserine yenik düşmüştür.

$\mathrm{Bu}$ çalışmada incelenecek olan özgün metin Interpretation and Overinterpretation 1990 yılında Tanner Lectures and Seminars isimli seminerde yapılan konuşmaların derlemesidir. Tanner Konferansları, 1978'de Clare Hall - Cambridge'de resmen başlatılmış ve takip eden yıllarda Harvard, Michigan, Utah, Oxford ve Stanford gibi dünyanın önde gelen üniversitelerinde düzenlenmiştir. 1990 yılında, Tanner Konferanslarını sunmak üzere Umberto Eco davet edilmiş ve üzerinde duracağı konuyu "Yorum ve Aşırı Yorum" olarak belirlemiştir. Konferansta Eco'nun yanı sıra, felsefe ve edebiyat teorisinin önde gelen isimlerinden Richard Rorty, Jonathan Culler, Christine Brooke-Rose ve Stefan Collini'nin de konuşmaları yer almaktadır. Konferansta yapılan konuşmalar 1992'de Cambridge University Press tarafından Interpretation and Overinterpretation başlığıyla yayımlanmıştır. Eco yapıtında metnin niyetinin olası yorumları ne şekilde sınırladığıyla ilgili görüşler bildirmektedir. Ardından, farklı bakış açılarıyla filozof Rorty, edebiyat kuramcısı Culler, eleştirmen ve roman yazarı Brook-Rose Eco'nun düşüncelerine karşı kendilerine has duruşlarıyla önermeler sunmaktadırlar. Eserde sırasıyla katılımcılar hakkında bir bölüm, Collini'nin alandan olmayan okurları esere hazırlamak için kaleme aldığı bir giriş bölümü yer almaktadır (1992, s. 1). Bu bölümü, Interpretation and history (1992, s. 23), Overinterpreting texts (1992, s. 45) ve Between author and text (1992, s. 67) başlıklarıyla Eco'nun yorum, tarih, metinleri aşırı yorumlama, yazar ve metin olgularını tartıştığı bölümler takip etmektedir. Eco'nun düşüncelerine karşılık olarak The pragmatis's progress (1992, s. 89) başlığıyla Rorty, In defence of overinterpretation (1992, s. 109) ile Culler, Palimpsest history (1992, s. 125) ile de Brooke-Rose kendi fikirlerini sunmuşlardır. Reply (1992, s. 139) başlıklı eserin son 
bölümünde ise Eco'nun adı geçen araştırmacıların savunularına verdiği yanıt yer almaktadır.

\section{2 Çevirmen, Çeviri Metin ve Çevirmenin Çeviri Sürecine İlişkin Görüşleri}

1962'de Ankara'da dünyaya gelen Kemal Atakay, lisans eğitimini İstanbul Üniversitesi Edebiyat Fakültesi İngiliz Dili ve Edebiyatı Bölümünde tamamlamıştır. Amerika Birleşik Devletleri Illinois Üniversitesi Karşılaştırmalı Edebiyat Bölümünde Ortaçağ-Rönesans İngiliz ve İtalyan Edebiyatları üzerine lisansüstü öğrenim görmüştür. Çeşitli dergilerde inceleme, çeviri ve eleştiri yazıları bulunan Atakay, Yeditepe Üniversitesi İngiliz Dili ve Edebiyatı Bölümünde karşılaştırmalı edebiyat dersleri vermiş, Umberto Eco, Dante Alighieri, Francesco Petrarca, Cesare Pavese, Italo Calvino, Octavio Paz gibi isimlerin yapıtlarını İngilizce ve İtalyancadan çevirilerle dilimize kazandırmıştır.

Atakay, Interpretation and Overinterpretation başlığıyla İngilizce yayımlanan eseri Yorum ve Aşırı Yorum başlığıyla Türkçeye kazandırmıştır. Eserin bölümlerine sadık kalınmış bunun yanı sıra çeviri metne Çevirmenin notu ve Dizin bölümleri eklenmiştir. Bu çalışmanın amacı doğrultusunda çeviri sürecini netleştirmek ve terimlerin çevirisiyle ilgili deneyimlerini irdelemek için çevirmen Kemal Atakay'a elektronik posta yolu ile ulaşılmış ve çalışmanın "Çalışmanın Araştırma Soruları" başlığında araştırma soruları yöneltilmiştir.

Çevirmen, Yorum ve Aşırı Yorum'u çevirirken herhangi bir hazırlığının olmadığını, her çözümü çeviri sürecinde bulduğunu belirtmiş, Umberto Eco ile görüşme ve fikir paylaşımı imkânının olmadığını eklemiştir. Atakay, terimlerin çevirisine yönelik ise şunları belirtmektedir:

Öncelikle, Yorum ve Aşırı Yorum'un terimler açısından büyük güçlükler içeren bir metin olmadığını belirtmem gerek. Elbette, bunu söylerken, bir noktayı göz ardı etmemeliyiz: Ben ve bu tür metinleri çeviren aşağı yukarı benim kuşağımdan çevirmenlerin, bir avantajı vardı. O da, deyim yerindeyse, altyapı çalışmasının yani, dilbilim, göstergebilim gibi alanlardaki terimlere karşılık bulma çalışmalarının- önceden yapıımış olmasıydı. Aynı şeyi, felsefe terimleri için de söylemek gerekir. Tabii, felsefe alanındaki terim çalışmaları daha da eskilere uzanıyor. Burada da, önemli terimler için karşılıklar bulunmuştu. Biz, bu hazır altyapıdan yararlandık. Burada, aklıma, felsefede Felsefe Terimleri Sözlügü ile Bedia Akarsu ve Felsefe Tarihi ile Macit Gökberk geliyor. Dilbilim ve göstergebilimde ise, öncelikle Berke Vardar'ın sözlüğünü; bir de, üniversiteden hocamız olan ve hem derslerinde hem yapıtlarında çeşitli terimleri kendisinden öğrendiğimiz Akşit Göktürk'ü anmak isterim. (K. Atakay, kişisel görüşme, Nisan 25, 2018)

Atakay'ın sözlerinden anlaşılacağı üzere, çevirmenin, Türkiye'de dilbilim, göstergebilim ve felsefe gibi alanlarda üretilmiş sözlüklerden yararlanması kuramsal bilgi içeren metinlerdeki terimleri Türkçeye aktarırken bir avantaj sağlamıştır. Çevirmen, 
aldığı lisans eğitiminin de çeviri sürecine ve terim çevirisine katkı sağladığını vurgulamaktadır.

Dilimizde henüz bir karşılığı olmayan terimlerin çevirisini yaparken ise deneyimlerini şu şekilde aktarmaktadır:

Burada, birkaç yöntem söz konusu: i) (özellikle çok yerleşik bir terim söz konusu ise), terimi özgün dilinde bırakıp dipnotla açıklama verme (mesela, Yorum ve Aşırı Yorum'un başlarında modus ponens için yaptığım gibi); ii) "şeffaf çeviri" diyebileceğim yöntem; yani özgün terimin, çeviriyi telkin etmesi (mesela, intentio auctoris / lectoris / operis için "yazarın / okurun / metnin niyeti" karşılığı; burada bir terim önerisinden çok, özgün terimin neredeyse birebir çevirisi söz konusu. Elbette, bu yöntemin bazı örneklerdeki işleyişini sorgulayabiliriz: Mesela, simpatia universale terimini "evrensel sempati" olarak çevirdiğimizde, belki simpatia sözcüğünün Rönesans dönemindeki teknik anlamını aktarmış olamıyoruz, ama okur bağlamdan aşağı yukarı o anlamı çıkarabiliyor); iii) bir tür öneri çeviri (mesela, Ing. overinterpretation ya da İt. sovrainterpretazione için "aşırı yorum". (K. Atakay, kişisel görüşme, Nisan 25, 2018)

Dilimizde karşılığı olmayan terimleri çevirirken üç durumla karşılaştığını belirten Atakay, bazı durumlarda dipnotlara başvurarak terimi özgün dilinde bırakmayı tercih ettiğini söylemektedir. Bazı durumlarda ise özgün terimin hemen hemen birebir çevirisini yapıp Türkçeye aktardığını, diğer bir deyişle şeffaf çeviri olarak adlandırdığı yöntemi kullandığını vurgularken bu yöntemin yine de sorgulanmaya açık olduğunun altını çizmektedir. Terim çevirisi sürecinde deneyimlediği üçüncü durum ise, özgün metinde var olan terime Türkçe karşılık önerdiği ve bir tür öneri çeviri olarak isimlendirdiği durumdur.

Atakay, dilbilim, çeviribilim ve göstergebilim sözlüklerinde karşılığı olup, kulağa eski gelen terimlerin kullanımına ya da bu terimlere alternatif olarak daha güncel tınısı olan yeni terim önerisine karşı tutumunu ise şu şekilde açıklamakta:

Bu soruya net bir cevap vermek kolay değil. Elbette, çevirmen açısından en önemli nokta, kullandığı sözcük ya da terimin okurda karşııı bulması, çağrışım yaratmasıdır. Ama bunun ölçüsü nedir, dayanağı nedir? Sanırım, tam bir ölçü verebilmek neredeyse imkânsız. Çoğu zaman, çeviriyi yaparken bazı çıkarımlarda bulunuyor, bir karşılığın değil de diğerinin okurda daha büyük bir karşılık bulacağını varsayıyoruz. (K. Atakay, kişisel görüşme, Nisan 25, 2018)

Çevirmenin verdiği yanıttan anlaşılacağı üzere, terimin erek okurda bir anlam yaratması gözetilen bir önceliktir. Buradan hareketle çevirmenin, erek kültür özelliklerine ve metnin bağlamına uygun, okurun zihninde anlam oluşturacak yeni terimlerin kullanılmasına olumlu yaklaştığı düşünülebilir. Ancak yine de, böyle bir durumla karşı karşıya kalındığında çevirmenin yeni bir terim üretmek için bir dayanağının olmadı̆̆ı, kendi alımlamasından ve öznel tercihlerinden hareketle, mesleki artalan bilgisi doğrultusunda terim önermek durumunda kaldığı sonucuna varılabilir. Konu ile ilgili olarak Wolfram Wills (1996, ss. 174-191) ve Jirí Levý (2000, ss. 148-159) de çevirinin bir 
problem çözme ve karar verme süreci olduğunu, kimi zaman çevirmenin yaratıcılığının ve sezgilerinin de bu süreçte rol oynadığını savunmaktadır.

\subsection{Terim Incelemesi}

Bu bölümde, öncelikle özgün ve çeviri metinde taranan ve sözlüklerde karşılığı bulunan terimlere yer verilecek, her terim Türkçeye yerleşiklik ve uygunluk bakımından ele alınacaktır. Ardından, sözlüklerde karşılığı bulunmayan terimler değerlendirilecek, çevirmenin önerdiği terimler dikkate alınarak ve Türkçe-Ingilizce/İngilizce-Türkçe ${ }^{7}$ sözlüklerden ve Türk Dil Kurumu'nun Büyük Türkçe Sözlüğü’nden ${ }^{8}$ yararlanılacaktır.

\subsection{1 Özgün ve Çeviri Metinde Yer Alan Terimlerden Taranan Sözlüklerde Bulunanlar}

Bu çalışmada, Interpretation and Overinterpretation adlı yapıtta ve Türkçe çevirisinde yer alan terimlerin karşılıkları, yukarıda adı geçen yedi sözlükte taranmıştır. Taranan sözlüklerde karşılıkları bulunan terimler, çevirmenin kullandığı karşılıklar, Türkçe terimlerin kaynağı ve terimlerin uygunluk/yerleşiklik durumları ile gerekli durumlarda sunulan öneriler Ekler bölümünde Tablo 2'de listelenmektedir.

Tablo 2'de sunulan veriler ışığında, taranan sözlüklerde bulunan terimlerden \%50'si (16 terimden 8'i) Terimsel Gereksinim ve Yaratıcılık Düzeyleri Şeması'na göre birincil gereksinim düzeyine aittir. Tamamlayıcı yaratıcılık gerektiren bu terimlerin sözlüklerde birden fazla karşılığı bulunmakla beraber, kararsızlığı gidermek amacıyla mevcut terimler arasında anlamı en iyi yansıttığı düşünülen terimlerde karar kılınabilir ${ }^{9}$. Tabloda sunulan terimlerden \%50'si (16 terimden 8'i) de sıfır gereksinim düzeyine ait olup sıfır yaratıcılık gerektirir. Bu terimlerin taranan sözlüklerde karşılıkları standartlaşmıştır ve yeni terim önerisine gerek yoktur. Verilerden hareketle, sözlüklerde taranan terim karşılıklarının yarısının birbiriyle yarış halinde olduğu ve halen standart hale ulaşmadığı anlaşılabilir.

\subsection{2 Özgün ve Çeviri Metinde Yer Alan Terimlerden Taranan Sözlüklerde Bulunmayanlar}

Özgün ve çeviri metinlerde yer alan terimlerden, taranan sözlüklerde bulunmayanlar için çevirmenin kullandığı birçok Türkçe karşılığın uygun olduğu gözlemlenmiştir. Taranan sözlüklerde yer almayan terimlerin elektronik sözlüklerde aranması ve anlamlarının karşılaştırılması sonucu İngilizce özgün yapıtta ve Türkçe çevirisinde önerilen terimlerin açıklamaları doğrultusunda yeni terim önerilerine gereksinim olduğu saptanmıştır. Tablo 3’te özgün metinde geçen terimler, çevirmenin önerdiği karşılıklar, terimlerin taranan

\footnotetext{
${ }^{7}$ Cambridge Dictionary English-Turkish Dictionary. http://dictionary.cambridge.org/dictionary/turkish Erişim Tarihi [23.09.2019]

Oxford Dictionaries. https://www.oxforddictionaries.com/ Erişim tarihi [23.09.2019]

Online Dictionaries by bab.la - Turkish-English/English-Turkish. https://en.bab.la Erişim tarihi [23.09.2019]

${ }^{8}$ Türk Dil Kurumu - Büyük Türkçe Sözlük. www.tdk.gov.tr Erişim tarihi [23.09.2019]

${ }^{9}$ Birden fazla karşılığı olan terimler arasında anlamı en iyi yansıttığı düşünülen terimlerde karar kılmak başka bir araştırmanın konusudur. Bu çalışmanın yöntemi olan betimleyici yaklaşımdan ziyade kuralcı yaklaşımla ve uygun alanyazın taramasıyla ele alındıktan sonra terim seçimi/önerisi yapılmalıdır.
} 
elektronik sözlüklerde bulunan sözlük anlamları ve yeni bir karşılığa gereksinimi olduğu düşünülen terimler sunulmuştur.

Tablo 3'teki verilerden hareketle, terimlerin \%31.09'u (74 terimden 23'ü) taranan sözlüklerde bulunmamasına rağmen, çeşitli akademik çalışmalarda ve kuramsal metinlerde hâlihazırda çevirmenin önerdiği şekilde kullanıldığı ve standart hale geldiği için sıfır gereksinim düzeyindedir ve çevirmen herhangi bir yaratıcılık düzeyine başvurmamıştır. Terimlerin \%45.94'üne (74 terimden 34'ü), mevcut bir karşılığı bulunmadığı için tam gereksinim durumunda iken çevirmen tarafından başvurulan zorunlu yaratıcılık düzeyi ile kavramın anlamsal içeriğinden yola çıkılarak terimleri en iyi yansıtacak öneriler getirilmiştir. Çevirmen tarafından terim önerisi getirilen terimler henüz standartlaşmadığı için birincil gereksinim düzeyine gelmişlerdir. Taranan sözlüklerde bulunmayan ve çevirmen tarafından terim karşılığı önerilen terimlerin \% 22.97'si (74 terimden 17'si) daha güncel bir kullanıma sahip olması için küçük müdahalelere ihtiyaç duyulduğu tespit edilmiştir. Ikincil gereksinim düzeyinde olan bu terimlere gerekli yaratıcılık düzeyi gözetilerek çevirmenin önerdiği terimden ayrı olarak yeni terimlerin önerilebileceği düşünülebilir ${ }^{10}$.

\section{Sonuç}

Bu çalışmada, terim ve terimbilim kavramları ele alınmış, terimbilimin işlevlerine yer verilmiştir. Çalışmanın ilerleyen bölümlerinde ise terim sorunlarına ve bu sorunların giderilmesinin çeviri çalışmalarına bağlı olduğuna vurgu yapılmış, bu bağlamda Türkiye'de terim araştırmalarına yönelik yapılan örnek bir çalışmaya (Öztürk Kasar \& Tuna, 2017) değinilmiştir. Söz konusu çalışmanın amacı, kuramsal ve yöntemsel bilgiler doğrultusunda terim araştırmalarından bir örnek durum çalışması ortaya koymak olarak belirlenmiş ve örneklem olarak Umberto Eco'nun Interpretation and Overinterpretation özgün metni ile Yorum ve Aşırı Yorum çeviri metni karşılaştırmalı olarak incelenmiş ve yapıtın çevirmeni Kemal Atakay'ın düşünce ve deneyimlerine de yer verilerek çeviri sürecine ışık tutulmuştur. Böyle bir çalışmada çevirmenin görüşlerinin yansıtılması ve henüz dilimizde karşılığı olmayan terimleri çevirirken izlediği yolların ve edindiği tecrübelerin sunulması, çeviri eğitimi almakta olan lisans ve lisansüstü düzeydeki çevirmen adayı öğrenciler için kuramsal çeviride terim aktarımının nasıl yapılabileceğine dair bazı yöntemler de sunmakta ve yaratıcılıklarını desteklemektedir.

Yürütülen incelemeler ve terim taramaları sonucunda eserde bulunan terimlerin \%50'sinin taranan sözlüklerde bulunmasına karşın, diğer yarısının standartlaşmış bir karşılığının bulunmadığı ve taranan sözlüklerde farklı terimlerle karşılandığı anlaşılmıştır. Taranan sözlüklerde bulunmayan terim karşılıklarının oranı \%68.91 olup; bu terimlerin \%45.94'ü çevirmen tarafından Türkçeye uygun şekilde aktarılmış, \%31.09'unun ise sözlüklerde bulunmadığı halde akademik yapıtlarda standart şekilde kullanıldığı kanısına

${ }^{10}$ Çevirmenin önerdiği terimlere alternatif terimler önermek için gerekli yaratıcılık düzeyleri de göz önünde bulundurularak başka bir araştırma konusu tasarlanabilir. 
varılmıştır. Bu araştırmada taranan terimler Öztürk Kasar’ın önerdiği Terimsel Gereksinim ve Yaratıcılık Düzeyleri Şeması ile gruplandırımış ve ele alınan bütünce derinlikli şekilde incelenerek terim çevirisinin boyutları ele alınmıştır. Bu bağlamda, Terimsel Gereksinim ve Yaratıcılık Düzeyleri Şeması'nın terim çevirisi ile ilgilenen araştırmacılar için çalışmalarında terim tararken başvuracakları bir yönlendirici olduğu düşünülmektedir.

Bu bulgulardan hareketle, dilbilim, göstergebilim ve çeviribilim sözlüklerinde bazı boşluklar olduğu, kullanımda olan terimlerin bir kısmının ise standart halde olmadığı sonucuna ulaşılmaktadır. Söz konusu terim boşluklarını kapatmak, çevirmenlerin işini kolaylaştırmak, kuramsal metin çevirisi yapan yetkin çevirmenler yetiştirmek ve Türkçede terim birliğini sağlamak amacıyla çeviri eğitimi veren kurumların ders programlarında terim çalışmalarına da ağırlık vermesi ve uzmanlık alanlarına göre sözlük çalışmalarında bulunması önerilmektedir.

$\mathrm{Bu}$ öneri doğrultusunda, çeviri kurumlarının ders programlarına eklenen terimbilim dersleri ile kuramsal metin çevirisinde yetkin çevirmen kimliğiyle hareket eden ve metnin tuzaklarından sıyrılan bilinçli çevirmenler yetiştirilmiş ve Türkçede geniş bir terim bankası hazırlanmış olacaktır.

\section{Kaynakça}

Altay, A. (2011). Initiating a terminology policy, the case of Turkey: TermTurk project. Magyar Terminológia, 4(2), 151-159. doi: 10.1556/MaTerm. 4.2011.2.3.

Altay, A., Alan, C. \& Ateşman, E. (2011). Towards a terminology centre: awareness, project, outcome. T. Kruyt, E. Ruijsendaal, W.J.R. Martin \& H.D. van der Vliet (Eds.), Terminology for Europeans (and beyond) (ss. 35-46). Gent: Academia Press.

Bengi-Öner, I. (2001). Çeviri terimleri sözlügü. İstanbul: Sel Yayıncılık.

Berg, B. L. (2001). Qualitative research methods for the social sciences. Boston: Allyn ve Bacon.

Berg, B. L. \& Lune, H. (2015). Sosyal bilimlerde nitel araştırma yöntemleri. (H. Aydın, Çev). Konya: Eğitim Yayınları.

Berk, Ö. (2005). Kuramlar ışığında açıklamalı çeviribilim terimcesi. İstanbul: Multilingual Yabancı Dil Yayınları.

Boztaş, i. \& Okyayuz Yener, Ş. (2005). Açıklamalı çeviri terimleri sözlüğü. Ankara: Siyasal Kitabevi.

Cambridge Dictionary English-Turkish Dictionary. http://dictionary.cambridge.org/dictionary/turkish Erişim tarihi [23.09.2019]

De Bessé. B. (2005). Terim sorunları. M. Durak (Ed.), Terimden anlama (M. Durak, Çev.) (ss. 5-31). İstanbul: Multilingual.

Duff, P. A. (2007). Case study research in applied linguistics. New York ve London: Routledge.

Eco, U. (1992). Interpretation and overinterpretation. Cambridge: Cambridge University Press 
Eco, U. (2011). Yorum ve aşırı yorum. (K. Atakay, Çev). İstanbul: Can Yayınları.

Eren, H., Parlatır, i., Tekin, T. \& Zülfikar, H. (1988). Terim. Türk Dil Kurumu Türkçe Sözlük içinde (Yeni Baskı. Cilt 2, s. 1458). Ankara: Türk Dil Kurumu Yayınları.

Erten, A. (1993). Çeviri ediminde kayıplar sorunu. Hacettepe Üniversitesi Edebiyat Fakültesi Dergisi, 10(1), 315-330.

Gözaydın, N. (2008). TDK'de çeviri çalışmaları. B. Gültekin (Ed.), Türkçe ve Çeviri Sorunları Çalıştayı (ss. 19-23). Ankara: Türk Dil Kurumu Yayınları.

Hacettepe Üniversitesi Mütercim Tercümanlık Bölümü. (2020, Haziran 20). Projeler. http://www.mtb.hacettepe.edu.tr/projeler.php

IAT. (1982). Termina News Bulletin 1(1). International Association for Terminology.

İmer, K., Kocaman, A. \& Özsoy, A. S. (2013). Dilbilim sözlüğü. İstanbul: Boğaziçi Üniversitesi Yayınevi.

Jakobson, R. (2000). On Linguistic aspects of translation. L. Venuti (Ed.), The Translation Studies Reader (ss. 113-118). Londra: Routledge.

Karaman, B. İ., (2017). Terimbilimi. İstanbul: Bilge Kültür Sanat.

Levý, J. (2000). Translation as a decision process. L. Venuti (Ed.), The Translation Studies Reader (ss. 148-159). London: Routledge.

Online Dictionaries by bab.la - Turkish-English/English-Turkish. https://en.bab.la Erişim tarihi [23.09.2019]

Oxford Dictionaries. https://www.oxforddictionaries.com/ Erişim tarihi [23.09.2019]

Öztürk Kasar, S. (2017). Algirdas Julien Greimas'ın sémantique structurale adlı yapıtını Türkçeye nasıl çevirmeli?. Ş. Öztürk (Ed.), Cogito, 86, 208-316.

Öztürk Kasar, S. \& Tuna, D. (2017). Sosyal bilimler alanında terimcelerin çevrilmesi ve türkçe terim üretimi. Turkish Studies International Periodical for the Languages, Literature and History of Turkish or Turkic, 12(13), 415-436. doi: http://dx.doi.org/10.7827/TurkishStudies.12027

Rifat, M. (2018). Açıklamalı göstergebilim sözlüğü. İstanbul: Alfa Yayınları.

Rifat, M., Rifat, S., Koş, A. \& Tekgül, D. (2010). Göstergebilim, dilbilim ve çeviribilim terimleri sözlügü. İstanbul: Sel Yayıncılık.

TermTurk, Kültürlerarası diyalog ve özel iletişim için terminoloji. http://www.termturk.org/objectives.php Erişim Tarihi [19.06.2020]

Türk Dil Kurumu - Büyük Türkçe Sözlük. www.tdk.gov.tr Erişim tarihi [23.09.2019]

Vardar, B. (1980). Terimsel etkinlik ve terimbilim. Türk Dili Edebiyat Dergisi, XLI, 385-389.

Vardar, B. (2005). Terimbilim ve yeni sözcükleme. M. Durak (Ed.), Terimden anlama (M. Durak, Çev.) (ss. 17-24). İstanbul: Multilingual.

Vardar, B., Güz, N., Huber, E., Senemoğlu, O. \& Öztokat, E. (2007). Açıklamalı dilbilim terimleri sözlüğü. İstanbul: Multilingual Yabancı Dil Yayınları. 
Wilss, W. (1996). Knowledge and skills in translator behaviour. Amsterdam ve Philadelphia: John Benjamins.

Yıldırım, A. \& Şimşek, H. (2013). Sosyal bilimlerde nitel araştırma yöntemleri. Ankara: Seçkin Yayıncılık.

Zülfikar, H. (2011). Terim sorunları ve terim yapma yolları. Ankara: Türk Dil Kurumu Yayınları.

\section{Ekler}

Tablo 2: Taranan Sözlüklerde Bulunan Terimler

\begin{tabular}{|c|c|c|c|c|c|}
\hline & $\begin{array}{l}\text { İngilizce } \\
\text { Terim ve } \\
\text { Sayfa } \\
\text { Numarası }\end{array}$ & $\begin{array}{l}\text { Çeviride } \\
\text { Kullanılan } \\
\text { Karşılık ve } \\
\text { Sayfa } \\
\text { Numarası }\end{array}$ & $\begin{array}{l}\text { Türkçe } \\
\text { Terimin } \\
\text { Sözlüklerde } \\
\text { Karşılığı }\end{array}$ & $\begin{array}{l}\text { Türkçe } \\
\text { Terimin } \\
\text { Kaynağı }\end{array}$ & $\begin{array}{l}\text { Terimin } \\
\text { Uygunluk/Yerleşiklik } \\
\text { Durumu }\end{array}$ \\
\hline & & & anıştırma & $\begin{array}{l}\text { Rifat vd. } \\
\text { Vardar vd. }\end{array}$ & \multirow[b]{2}{*}{$\begin{array}{l}\text { Çevirmenin tercih ettiği } \\
\text { terim sözlüklerde } \\
\text { geçmektedir. Terim karşılığı } \\
\text { sözlüklerde "anıştırma" ve } \\
\text { "telmih" olarak verilmiştir. } \\
\text { Standart bir terim karşılığı } \\
\text { bulunmamakla birlikte } \\
\text { tamamlayıcı yaratıcılığa } \\
\text { ihtiyaç } \\
\begin{array}{l}\text { düşünülebilir. } \\
\text { gereksinim) }\end{array}\end{array}$} \\
\hline 1 & $\begin{array}{l}\text { allusion } \\
30\end{array}$ & $\begin{array}{l}\text { anıştırma } \\
47\end{array}$ & telmih & Rifat vd. & \\
\hline 2 & $\begin{array}{l}\text { analogy } \\
76\end{array}$ & $\begin{array}{l}\text { analoji } \\
65\end{array}$ & örnekseme & $\begin{array}{l}\text { Vardar vd. } \\
\text { Imer vd. } \\
\text { Rifat vd. }\end{array}$ & $\begin{array}{l}\text { Sözlüklerden yola çıkarak } \\
\text { "örnekseme" sözcüğünün } \\
\text { kullanımda ve yerleşik } \\
\text { olduğu düşünülebilir. (sıfır } \\
\text { gereksinim) }\end{array}$ \\
\hline 3 & $\begin{array}{l}\text { antonoma } \\
\text { sia } \\
46\end{array}$ & $\begin{array}{l}\text { dolaylı } \\
\text { adlama } \\
64\end{array}$ & adsayma & $\begin{array}{l}\text { Imer vd. } \\
\text { Vardar vd. }\end{array}$ & $\begin{array}{l}\text { Özel bir adın simge olarak } \\
\text { kullanılması anlamına gelen } \\
\text { "antonomasia"nın karşıı̆ı } \\
\text { olarak sözlüklerde } \\
\text { "adsayma" bulunmaktadır. } \\
\text { Dolayısı ile terim uygun ve } \\
\text { yerleşiktir. (sıfır gereksinim) }\end{array}$ \\
\hline \multirow{2}{*}{4} & \multirow{2}{*}{$\begin{array}{l}\text { contrast } \\
46\end{array}$} & \multirow{2}{*}{$\begin{array}{l}\text { karşıtlık } \\
64\end{array}$} & aykırılık & $\begin{array}{l}\text { Vardar vd. } \\
\text { Rifat vd. } \\
\text { Rifat }\end{array}$ & \multirow{2}{*}{$\begin{array}{l}\text { "Aykırılık" terimi } \\
\text { sözlüklerde yerleşik değildir, } \\
\text { "karşıtlık" olarak da } \\
\text { kullanılmaktadır. } \\
\begin{array}{l}\text { Tamamlayıcı yaratıcılığa } \\
\text { ihtiyaç }\end{array} \text { duyulduğu } \\
\begin{array}{l}\text { düşünülebilir. } \\
\text { gereksinim) }\end{array}\end{array}$} \\
\hline & & & karşıtlık & Imer vd. & \\
\hline
\end{tabular}




\begin{tabular}{|c|c|c|c|c|c|}
\hline \multirow{3}{*}{5} & \multirow{3}{*}{$\begin{array}{l}\text { economy } \\
49\end{array}$} & \multirow{3}{*}{$\begin{array}{l}\text { iktisat } \\
67\end{array}$} & $\begin{array}{l}\text { tutumluluk } \\
\text { düzen }\end{array}$ & Rifat vd. & \multirow{3}{*}{$\begin{array}{lr}\text { Sözlüklerde } & \text { "economy" } \\
\text { teriminin } & \text { karşıllığı farklı } \\
\text { şekillerde } & \text { verilmiştir. } \\
\text { Dolayısı ile } & \text { terim yerleşik } \\
\text { değildir. } & \text { Tamamlayıcı } \\
\text { yaratıcılığa } & \text { ihtiyaç } \\
\text { duyulduğu düşünülebilir. } \\
\text { (birincil gereksinim) }\end{array}$} \\
\hline & & & ekonomi & Boztaş vd. & \\
\hline & & & daraltma & Berk & \\
\hline 6 & $\begin{array}{l}\text { homonym } \\
\text { y } \\
46\end{array}$ & $\begin{array}{l}\text { eşadlılık } \\
64\end{array}$ & eşadlılık & $\begin{array}{l}\text { Vardar vd. } \\
\text { Rifat vd. } \\
\text { Imer vd. }\end{array}$ & $\begin{array}{l}\text { Terim yerleşik ve uygundur. } \\
\text { (sıfır gereksinim) }\end{array}$ \\
\hline 7 & $\begin{array}{l}\text { image } \\
46\end{array}$ & $\begin{array}{l}\text { imge } \\
64\end{array}$ & $\begin{array}{l}\text { görüntü } \\
\text { imge }\end{array}$ & Rifat vd. & 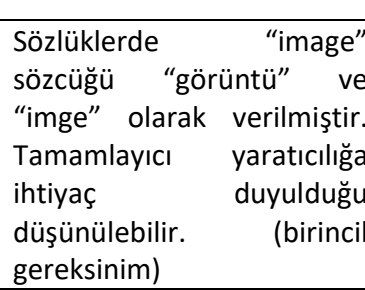 \\
\hline 8 & $\begin{array}{l}\text { lexeme } \\
62\end{array}$ & $\begin{array}{l}\text { sözlükbirim } \\
83\end{array}$ & sözlükbirim & $\begin{array}{l}\text { Vardar vd. } \\
\text { Rifat vd. } \\
\text { Imer vd. }\end{array}$ & $\begin{array}{lr}\begin{array}{l}\text { Terim yerleşik } \\
\text { kullanımdadır. }\end{array} & \begin{array}{r}\text { ve } \\
\text { (sıfır } \\
\text { gereksinim) }\end{array}\end{array}$ \\
\hline \multirow{3}{*}{9} & \multirow{3}{*}{$\begin{array}{l}\text { metaphor } \\
63\end{array}$} & \multirow{3}{*}{$\begin{array}{l}\text { eğretileme } \\
83\end{array}$} & eğretileme & $\begin{array}{l}\text { Vardar vd. } \\
\text { Boztaş vd. } \\
\text { Imer vd. } \\
\text { Rifat vd. }\end{array}$ & \multirow{3}{*}{ 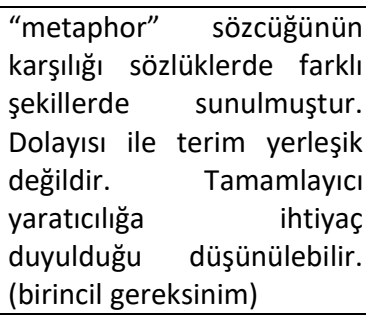 } \\
\hline & & & $\begin{array}{l}\text { deyim } \\
\text { aktarması }\end{array}$ & Imer vd. & \\
\hline & & & metafor & Rifat vd. & \\
\hline \multirow{2}{*}{10} & \multirow{2}{*}{$\begin{array}{l}\text { metonom } \\
y \\
46\end{array}$} & \multirow{2}{*}{$\begin{array}{l}\text { düzdeğişme } \\
\text { ce } \\
64\end{array}$} & $\begin{array}{l}\text { düzdeğişme } \\
\text { ce }\end{array}$ & $\begin{array}{l}\text { Imer vd. } \\
\text { Rifat vd. }\end{array}$ & \multirow{2}{*}{$\begin{array}{l}\text { Terim yerleşik ve } \\
\text { kullanımdadır. (sıfır } \\
\text { gereksinim) }\end{array}$} \\
\hline & & & ad aktarımı & Imer vd. & \\
\hline 11 & $\begin{array}{l}\text { motif } \\
60\end{array}$ & $\begin{array}{l}\text { izlek } \\
80\end{array}$ & motif & Rifat vd. & $\begin{array}{l}\text { Terim yerleşiktir (sıfır } \\
\text { gereksinim) }\end{array}$ \\
\hline \multirow[t]{2}{*}{12} & \multirow[t]{2}{*}{$\begin{array}{l}\text { referent } \\
43\end{array}$} & \multirow[t]{2}{*}{$\begin{array}{l}\text { gönderge } \\
61\end{array}$} & gönderge & $\begin{array}{l}\text { Vardar vd. } \\
\text { Imer vd. } \\
\text { Rifat } \\
\text { Rifat vd. }\end{array}$ & \multirow{2}{*}{$\begin{array}{l}\text { Terim yerleşik ve } \\
\text { kullanımdadır. (sıfır } \\
\text { gereksinim) }\end{array}$} \\
\hline & & & gönderilen & Rifat vd. & \\
\hline 13 & $\begin{array}{l}\text { semiosis } \\
24\end{array}$ & $\begin{array}{l}\text { semiosis } \\
39\end{array}$ & $\begin{array}{l}\text { göstergesel } \\
\text { işlev }\end{array}$ & $\begin{array}{l}\text { Vardar vd. } \\
\text { Imer vd. }\end{array}$ & $\begin{array}{l}\text { "semiosis" terimi } \\
\text { sözlüklerde Türkçeye farklı }\end{array}$ \\
\hline
\end{tabular}


Terimbilim Odağında ve Çevirmenin Tanıklığında Kuramsal Çeviri

\begin{tabular}{|c|c|c|c|c|c|}
\hline & & & semiosis & Rifat & $\begin{array}{l}\text { şekillerde aktarılmıştır. } \\
\text { Dolayısı ile terim yerleşik } \\
\text { değildir. Tamamlayıcı } \\
\text { yaratıcılığa ihtiyaç } \\
\text { duyulduğu düşünülebilir. } \\
\text { (birincil gereksinim) }\end{array}$ \\
\hline 14 & $\begin{array}{l}\text { sign } \\
46\end{array}$ & $\begin{array}{l}\text { iz } \\
64\end{array}$ & gösterge & $\begin{array}{l}\text { Vardar vd. } \\
\text { Rifat } \\
\text { Rifat vd. } \\
\text { Imer vd. }\end{array}$ & $\begin{array}{l}\text { "sign" teriminin karşılığı } \\
\text { olarak sözlüklerde } \\
\text { "gösterge" terimi } \\
\text { verilmektedir. Terim } \\
\text { yerleşiktir. (sıfır gereksinim) }\end{array}$ \\
\hline \multirow{4}{*}{15} & \multirow{4}{*}{$\begin{array}{l}\text { style } \\
69\end{array}$} & \multirow{4}{*}{$\begin{array}{l}\text { üslup } \\
89\end{array}$} & biçem & $\begin{array}{l}\text { Vardar vd. } \\
\text { Imer, vd. } \\
\text { Rifat, vd. }\end{array}$ & \multirow{4}{*}{$\begin{array}{l}\text { "style" terimi sözlüklerde } \\
\text { Türkçeye farklı şekillerde } \\
\text { aktarılmıştır. Dolayısı ile } \\
\text { terim yerleşik değildir. } \\
\text { Tamamlayıcı yaratıcılığa } \\
\text { ihtiyaç duyulduğu } \\
\text { düşünülebilir. (birincil } \\
\text { gereksinim) }\end{array}$} \\
\hline & & & deyiş & $\begin{array}{l}\text { Vardar vd. } \\
\text { Imer, vd. } \\
\text { Rifat, vd. }\end{array}$ & \\
\hline & & & üslup & Rifat, vd. & \\
\hline & & & anlatım & Rifat, vd. & \\
\hline \multirow[b]{2}{*}{16} & \multirow{2}{*}{$\begin{array}{l}\text { symbol } \\
46\end{array}$} & \multirow{2}{*}{$\begin{array}{l}\text { simge } \\
64\end{array}$} & simge & $\begin{array}{l}\text { Vardar vd. } \\
\text { Rifat vd. } \\
\text { Rifat }\end{array}$ & \multirow{2}{*}{$\begin{array}{l}\text { "symbol" terimi sözlüklerde } \\
\text { Türkçeye farklı şekillerde } \\
\text { aktarılmıştır. Dolayısı ile } \\
\text { terim yerleşik değildir. } \\
\text { Tamamlayıcı yaratıcılığa } \\
\text { ihtiyaç duyulduğu } \\
\text { düşünülebilir. (birincil } \\
\text { gereksinim) }\end{array}$} \\
\hline & & & sembol & Rifat & \\
\hline
\end{tabular}

Tablo 3: Taranan Sözlüklerde Bulunmayan Terimler

\begin{tabular}{|c|l|l|l|l|}
\hline \multicolumn{1}{|c|}{$\begin{array}{c}\text { Ingilizce } \\
\text { Sayfa } \\
\text { Numarası }\end{array}$} & $\begin{array}{c}\text { Çeviride } \\
\text { Önerilen } \\
\text { Karşılık }\end{array}$ & Sözlük Anlamı & \multicolumn{1}{|c|}{$\begin{array}{c}\text { Değerlendirme ve Gereksinim } \\
\text { Durumu }\end{array}$} \\
\hline 1 & $\begin{array}{l}\text { act of } \\
\text { reading } \\
68\end{array}$ & $\begin{array}{l}\text { okuma } \\
\text { edimi } \\
88\end{array}$ & $\begin{array}{l}\text { act: edim, } \\
\text { eylem, hareket, } \\
\text { performans }\end{array}$ & $\begin{array}{l}\text { Çevirmenin Türkçeye aktardığı } \\
\text { terim literatürde yerleşiktir ve } \\
\text { kullanılmaktadır. (sıfır gereksinim- } \\
\text { sıfır yaratıcılık) }\end{array}$ \\
\hline 2 & $\begin{array}{l}\text { arguable } \\
\text { intention }\end{array}$ & $\begin{array}{l}\text { tartışmaya } \\
\text { açık niyet } \\
99\end{array}$ & $\begin{array}{l}\text { arguable: } \\
\text { tartışıabilir, } \\
\text { tartışmaya açık, } \\
\text { tartışmalı, } \\
\text { doğruluğu belli } \\
\text { olmayan }\end{array}$ & $\begin{array}{l}\text { Terim literatürde yerleşik değildir. } \\
\text { Dolayısı ile yeni terim gereksinimine } \\
\text { açık olduğu düşünülebilir. (ikincil } \\
\text { gereksinim-gerekli yaratıcılık) }\end{array}$ \\
\hline
\end{tabular}




\begin{tabular}{|c|c|c|c|c|}
\hline 3 & $\begin{array}{l}\text { associative } \\
\text { automatisms } \\
46\end{array}$ & $\begin{array}{l}\text { çağrışım } \\
\text { yöntemleri } \\
64\end{array}$ & $\begin{array}{l}\text { automatism: } \\
\text { otomasyon, } \\
\text { özdevim, } \\
\text { özedim, } \\
\text { özişlerlik }\end{array}$ & $\begin{array}{l}\text { Terim literatürde yerleşik değildir. } \\
\text { Dolayısı ile yeni terim gereksinimine } \\
\text { açık olduğu düşünülebilir. (ikincil } \\
\text { gereksinim-gerekli yaratıcılık) }\end{array}$ \\
\hline 4 & $\begin{array}{l}\text { close } \\
\text { reading } \\
139\end{array}$ & $\begin{array}{l}\text { yakın } \\
\text { okuma } \\
167\end{array}$ & & $\begin{array}{l}\text { Çeviride kullanılan karşılık uygun } \\
\text { görülmektedir ancak terim standart } \\
\text { değildir. Türkçedeki terim açığını } \\
\text { gidermek için tamamlayıcı bir } \\
\text { yaratıcılık gösterilmiştir. Dolayısıyla, } \\
\text { terim için, "tam gereksinim" } \\
\text { durumunda üretilmiş kabul } \\
\text { edilebilir bir terim önerisi olduğu } \\
\text { söylenebilir. (birincil gereksinim- } \\
\text { tamamlayıcı yaratıcılık) }\end{array}$ \\
\hline 5 & $\begin{array}{l}\text { competence } \\
\text { of the } \\
\text { reader } \\
68\end{array}$ & $\begin{array}{l}\text { okurun } \\
\text { yetisi } \\
88\end{array}$ & $\begin{array}{l}\text { competence: } \\
\text { yeterlik, yeti, } \\
\text { kabiliyet, edinç }\end{array}$ & $\begin{array}{l}\text { Çevirmenin Türkçeye aktardığı } \\
\text { terim literatürde yerleşiktir ve } \\
\text { kullanılmaktadır. (sıfır gereksinim- } \\
\text { sıfır yaratıcılık) }\end{array}$ \\
\hline 6 & $\begin{array}{l}\text { concealed } \\
\text { message } \\
72\end{array}$ & $\begin{array}{l}\text { gizli ileti } \\
93\end{array}$ & $\begin{array}{l}\text { concealed: } \\
\text { gizlenmiş, gizli, } \\
\text { saklı }\end{array}$ & $\begin{array}{l}\text { Çeviride kullanılan karşılık uygun } \\
\text { görülmektedir ancak terim standart } \\
\text { değildir. Türkçedeki terim açığını } \\
\text { gidermek için tamamlayıcı bir } \\
\text { yaratıcılık gösterilmiştir. Dolayısıla, } \\
\text { terim için, "tam gereksinim" } \\
\text { durumunda üretilmiş kabul } \\
\text { edilebilir bir terim önerisi olduğu } \\
\text { söylenebilir. (birincil gereksinim- } \\
\text { tamamlayıcı yaratıcılık) }\end{array}$ \\
\hline 7 & $\begin{array}{l}\text { conjecture of } \\
\text { the } \\
\text { reader } \\
64\end{array}$ & $\begin{array}{l}\text { okurun } \\
\text { tahmini } \\
84\end{array}$ & $\begin{array}{l}\text { conjecture: } \\
\text { varsayım, } \\
\text { tahmin, zan, } \\
\text { farz }\end{array}$ & $\begin{array}{l}\text { Çeviride kullanılan karşılık uygun } \\
\text { görülmektedir ancak terim standart } \\
\text { değildir. Türkçedeki terim açığını } \\
\text { gidermek için tamamlayıcı bir } \\
\text { yaratıcılık gösterilmiştir. Dolayısıyla, } \\
\text { terim için, "tam gereksinim" } \\
\text { durumunda üretilmiş kabul } \\
\text { edilebilir bir terim önerisi olduğu } \\
\text { söylenebilir. (birincil gereksinim- } \\
\text { tamamlayıcı yaratıcılık) }\end{array}$ \\
\hline 8 & $\begin{array}{l}\text { contemporary } \\
\text { reader } \\
68\end{array}$ & $\begin{array}{l}\text { çağdaş okur } \\
88\end{array}$ & & $\begin{array}{l}\text { Çeviride kullanılan karşılık uygun } \\
\text { görülmektedir ancak terim standart } \\
\text { değildir. Türkçedeki terim açığını } \\
\text { gidermek için tamamlayıcı bir } \\
\text { yaratıcılık gösterilmiştir. Dolayısıyla, } \\
\text { terim için, "tam gereksinim" } \\
\text { durumunda üretilmiş kabul } \\
\text { edilebilir bir terim önerisi olduğu }\end{array}$ \\
\hline
\end{tabular}


Terimbilim Odağında ve Çevirmenin Tanıklığında Kuramsal Çeviri

\begin{tabular}{|c|c|c|c|c|}
\hline & & & & $\begin{array}{l}\text { söylenebilir. (birincil gereksinim- } \\
\text { tamamlayıcı yaratıcılık) }\end{array}$ \\
\hline 9 & $\begin{array}{l}\text { conventional } \\
\text { meaning } \\
78\end{array}$ & $\begin{array}{l}\text { uzlaşımsal } \\
\text { anlam } \\
99\end{array}$ & $\begin{array}{l}\text { conventional: } \\
\text { adetlere uygun, } \\
\text { geleneksel, } \\
\text { uygun }\end{array}$ & $\begin{array}{l}\text { Çeviride kullanılan karşılık uygun } \\
\text { görülmektedir ancak terim standart } \\
\text { değildir. Türkçedeki terim açığını } \\
\text { gidermek için tamamlayıcı bir } \\
\text { yaratıcılık gösterilmiştir. Dolayısıyla, } \\
\text { terim için, "tam gereksinim" } \\
\text { durumunda üretilmiş kabul } \\
\text { edilebilir bir terim önerisi olduğu } \\
\text { söylenebilir. (birincil gereksinim- } \\
\text { tamamlayıcı yaratııılık) }\end{array}$ \\
\hline 10 & $\begin{array}{l}\text { creative text } \\
140\end{array}$ & $\begin{array}{l}\text { yaratıcı } \\
\text { metin } \\
168\end{array}$ & & $\begin{array}{l}\text { Çeviride kullanılan karşılık uygun } \\
\text { görülmektedir ancak terim standart } \\
\text { değildir. Türkçedeki terim açığını } \\
\text { gidermek için tamamlayıcı bir } \\
\text { yaratıcılık gösterilmiştir. Dolayısıyla, } \\
\text { terim için, "tam gereksinim" } \\
\text { durumunda üretilmiş kabul } \\
\text { edilebilir bir terim önerisi olduğu } \\
\text { söylenebilir. (birincil gereksinim- } \\
\text { tamamlayıcı yaratıcılık) }\end{array}$ \\
\hline 11 & $\begin{array}{l}\text { criterion of } \\
\text { similarity } \\
45\end{array}$ & $\begin{array}{l}\text { benzerlik } \\
\text { ölçütü } \\
63\end{array}$ & & $\begin{array}{l}\text { Çeviride kullanılan karşılık uygun } \\
\text { görülmektedir ancak terim standart } \\
\text { değildir. Türkçedeki terim açığını } \\
\text { gidermek için tamamlayıcı bir } \\
\text { yaratıcılık gösterilmiştir. Dolayısıla, } \\
\text { terim için, "tam gereksinim" } \\
\text { durumunda üretilmiş kabul } \\
\text { edilebilir bir terim önerisi olduğu } \\
\text { söylenebilir. (birincil gereksinim- } \\
\text { tamamlayıcı yaratıcılık) }\end{array}$ \\
\hline 12 & $\begin{array}{l}\text { cultural } \\
\text { framework } \\
68\end{array}$ & $\begin{array}{l}\text { kültürel } \\
\text { çerçeve } \\
89\end{array}$ & $\begin{array}{l}\text { framework: } \\
\text { temel yapı, } \\
\text { iskelet, düzen, } \\
\text { sistem }\end{array}$ & $\begin{array}{l}\text { Çevirmenin Türkçeye aktardığı } \\
\text { terim literatürde yerleşiktir ve } \\
\text { kullanılmaktadır. (sıfır gereksinim- } \\
\text { sıfır yaratıcılık) }\end{array}$ \\
\hline 13 & $\begin{array}{l}\text { cultural } \\
\text { conventions } \\
68\end{array}$ & $\begin{array}{l}\text { kültürel } \\
\text { gelenekler } \\
88\end{array}$ & & $\begin{array}{l}\text { Çevirmenin Türkçeye aktardığı } \\
\text { terim literatürde yerleşiktir ve } \\
\text { kullanılmaktadır. (sıfır gereksinim- } \\
\text { sıfır yaratıcılık) }\end{array}$ \\
\hline 14 & $\begin{array}{l}\text { drive of the } \\
\text { reader } \\
65\end{array}$ & $\begin{array}{l}\text { okur(un) } \\
\text { itkisi } \\
85\end{array}$ & $\begin{array}{l}\text { drive: enerji, } \\
\text { azim, şevk, } \\
\text { çaba, gayret, } \\
\text { girişim }\end{array}$ & $\begin{array}{l}\text { Terim literatürde yerleşik değildir. } \\
\text { Dolayısı ile yeni terim gereksinimine } \\
\text { açık olduğu düşünülebilir. (ikincil } \\
\text { gereksinim-gerekli yaratıcılık) }\end{array}$ \\
\hline 15 & $\begin{array}{l}\text { empirical } \\
\text { author } \\
64\end{array}$ & $\begin{array}{l}\text { ampirik } \\
\text { yazar } \\
84\end{array}$ & & $\begin{array}{l}\text { Çevirmenin Türkçeye aktardığı } \\
\text { terim literatürde yerleşiktir ve }\end{array}$ \\
\hline
\end{tabular}




\begin{tabular}{|c|c|c|c|c|}
\hline & & & & $\begin{array}{l}\text { kullanılmaktadır. (sıfır gereksinim- } \\
\text { sıfır yaratıcılık) }\end{array}$ \\
\hline 16 & $\begin{array}{l}\text { empirical } \\
\text { reader } \\
64\end{array}$ & $\begin{array}{l}\text { ampirik } \\
\text { okur } \\
84\end{array}$ & & $\begin{array}{l}\text { Çevirmenin Türkçeye aktardığı } \\
\text { terim literatürde yerleşiktir ve } \\
\text { kullanılmaktadır. (sıfır gereksinim- } \\
\text { sıfır yaratıcılık) }\end{array}$ \\
\hline 17 & $\begin{array}{l}\text { encyclopedia } \\
65\end{array}$ & $\begin{array}{l}\text { ansiklopedi } \\
85\end{array}$ & & $\begin{array}{l}\text { Terim, taranan sözlüklerde } \\
\text { bulunmamaktadır ancak çevirmenin } \\
\text { kullandığı karşılık Eco'nun diğer } \\
\text { kuramsal yapıtlarında da } \\
\text { ansiklopedi şeklinde çevrilmiştir. } \\
\begin{array}{l}\text { Dolayısıyla terim yerleşik bir hale } \\
\text { gelmiştir. (sıfır gereksinim-sıfır } \\
\text { yaratıcılık) }\end{array}\end{array}$ \\
\hline 18 & $\begin{array}{l}\text { idiolectal } \\
\text { association } \\
46\end{array}$ & $\begin{array}{l}\text { kişinin } \\
\text { kendine } \\
\text { özgü } \\
\text { diline bağlı } \\
\text { çağrışım } \\
65\end{array}$ & $\begin{array}{l}\text { idiolectal: birey } \\
\text { dil, bireysel dil, } \\
\text { bireysel } \\
\text { kullanım }\end{array}$ & $\begin{array}{l}\text { Terim literatürde yerleşik değildir. } \\
\text { Dolayısı ile yeni terim gereksinimine } \\
\text { açık olduğu düşünülebilir. (ikincil } \\
\text { gereksinim-gerekli yaratıcılık) }\end{array}$ \\
\hline 19 & $\begin{array}{l}\text { illusion of } \\
\text { meaning } \\
39\end{array}$ & $\begin{array}{l}\text { anlam } \\
\text { yanılsaması } \\
58\end{array}$ & $\begin{array}{l}\text { illusion: } \\
\text { yanılsama, } \\
\text { aldatıcı } \\
\text { görünüş, göz } \\
\text { aldanması }\end{array}$ & $\begin{array}{l}\text { Çeviride kullanılan karşılık uygun } \\
\text { görülmektedir. (sıfır gereksinim-sıfır } \\
\text { yaratıcılık) }\end{array}$ \\
\hline 20 & $\begin{array}{l}\text { infinite } \\
\text { conjecture } \\
64\end{array}$ & $\begin{array}{l}\text { sonsuz } \\
\text { tahmin } \\
84\end{array}$ & & $\begin{array}{l}\text { Çeviride kullanılan karşılık uygun } \\
\text { görülmektedir ancak terim standart } \\
\text { değildir. Türkçedeki terim açığını } \\
\text { gidermek için tamamlayıcı bir } \\
\text { yaratıcılık gösterilmiştir. Dolayısıyla, } \\
\text { terim için, "tam gereksinim" } \\
\text { durumunda üretilmiş kabul } \\
\text { edilebilir bir terim önerisi olduğu } \\
\text { söylenebilir. (birincil gereksinim- } \\
\text { tamamlayıcı yaratıcılık) }\end{array}$ \\
\hline 21 & $\begin{array}{l}\text { initiative of } \\
\text { the reader } \\
64\end{array}$ & $\begin{array}{l}\text { okurun } \\
\text { girişimi } \\
84\end{array}$ & & $\begin{array}{l}\text { Çeviride kullanılan karşılık uygun } \\
\text { görülmektedir ancak terim standart } \\
\text { değildir. Türkçedeki terim açığını } \\
\text { gidermek için tamamlayıcı bir } \\
\text { yaratıcılık gösterilmiştir. Dolayısıyla, } \\
\text { terim için, "tam gereksinim" } \\
\text { durumunda üretilmiş kabul } \\
\text { edilebilir bir terim önerisi olduğu } \\
\text { söylenebilir. (birincil gereksinim- } \\
\text { tamamlayıcı yaratıcılık) }\end{array}$ \\
\hline 22 & $\begin{array}{l}\text { intentio } \\
\text { auctoris }\end{array}$ & $\begin{array}{l}\text { yazarın } \\
\text { niyeti }\end{array}$ & & $\begin{array}{l}\text { Kabul edilebilir bir çeviri önerisi } \\
\text { olup, Eco'nun Latinceden devşirdiği }\end{array}$ \\
\hline
\end{tabular}


Terimbilim Odağında ve Çevirmenin Tanıklığında Kuramsal Çeviri

\begin{tabular}{|c|c|c|c|c|}
\hline & 25 & 41 & & $\begin{array}{l}\text { bu terim diğer metinlerinde de bu } \\
\text { haliyle kullanılmaktadır.(sıfır } \\
\text { gereksinim-sıfır yaratıcılık) }\end{array}$ \\
\hline 23 & $\begin{array}{l}\text { intentio } \\
\text { operis } \\
25\end{array}$ & $\begin{array}{l}\text { metnin } \\
\text { niyeti } \\
41\end{array}$ & & $\begin{array}{l}\text { Kabul edilebilir bir çeviri önerisi } \\
\text { olup, Eco'nun Latinceden devşirdiği } \\
\text { bu terim diğer metinlerinde de bu } \\
\text { haliyle kullanılmaktadır.(sıfır } \\
\text { gereksinim-sıfır yaratıcılık) }\end{array}$ \\
\hline 24 & $\begin{array}{l}\text { intention of } \\
\text { the reader } \\
64\end{array}$ & $\begin{array}{l}\text { okurun } \\
\text { niyeti } \\
84\end{array}$ & & $\begin{array}{l}\text { Çevirmenin Türkçeye aktardığı } \\
\text { terim literatürde yerleşiktir ve } \\
\text { kullanılmaktadır. (sıfır gereksinim- } \\
\text { sıfır yaratıcılık) }\end{array}$ \\
\hline 25 & $\begin{array}{l}\text { interpretative } \\
\text { bet } \\
63\end{array}$ & $\begin{array}{l}\text { yorumsal } \\
\text { bahis } \\
83\end{array}$ & $\begin{array}{l}\text { bet: bahis, iddia } \\
\text { bahis: üzerinde } \\
\text { konuşulan şey, } \\
\text { konu } \\
\text { iddia: sav, } \\
\text { kendinde } \\
\text { olmayan bir } \\
\text { yeteneği, bir } \\
\text { durumu varmış } \\
\text { gibi gösterme }\end{array}$ & $\begin{array}{l}\text { Çeviride kullanılan karşılık uygun } \\
\text { görülmektedir ancak terim standart } \\
\text { değildir. Türkçedeki terim açığını } \\
\text { gidermek için tamamlayıcı bir } \\
\text { yaratıcılık gösterilmiştir. Dolayısıyla, } \\
\text { terim için, "tam gereksinim" } \\
\text { durumunda üretilmiş kabul } \\
\text { edilebilir bir terim önerisi olduğu } \\
\text { söylenebilir. (birincil gereksinim- } \\
\text { tamamlayıcı yaratıcılık) }\end{array}$ \\
\hline 26 & $\begin{array}{l}\text { interpretive } \\
\text { criterion } \\
45\end{array}$ & $\begin{array}{l}\text { yorum } \\
\text { ölçütü } \\
63\end{array}$ & $\begin{array}{l}\text { criterion: kriter, } \\
\text { ölçüt, kıstas, } \\
\text { değer birimi }\end{array}$ & $\begin{array}{l}\text { Çeviride kullanılan karşılık uygun } \\
\text { görülmektedir ancak terim standart } \\
\text { değildir. Türkçedeki terim açığını } \\
\text { gidermek için tamamlayıcı bir } \\
\text { yaratıcılık gösterilmiştir. Dolayısıyla, } \\
\text { terim için, "tam gereksinim" } \\
\text { durumunda üretilmiş kabul } \\
\text { edilebilir bir terim önerisi olduğu } \\
\text { söylenebilir. (birincil gereksinim- } \\
\text { tamamlayıcı yaratıcılık) }\end{array}$ \\
\hline 27 & $\begin{array}{l}\text { intersubjectiv } \\
\text { e means } \\
149\end{array}$ & $\begin{array}{l}\text { Öznelerarası } \\
\text { araç } \\
178\end{array}$ & $\begin{array}{l}\text { intersubjective: } \\
\text { Bir gözlemin, } \\
\text { başka bir } \\
\text { gözlemci } \\
\text { tarafından } \\
\text { yinelenmesi } \\
\text { durumunda } \\
\text { taşıdığı özellik. }\end{array}$ & $\begin{array}{l}\text { Çeviride kullanılan karşılık uygun } \\
\text { görülmektedir ancak terim standart } \\
\text { değildir. Türkçedeki terim açığını } \\
\text { gidermek için tamamlayıcı bir } \\
\text { yaratıcılık gösterilmiştir. Dolayısıyla, } \\
\text { terim için, "tam gereksinim" } \\
\text { durumunda üretilmiş kabul } \\
\text { edilebilir bir terim önerisi olduğu } \\
\text { söylenebilir. (birincil gereksinim- } \\
\text { tamamlayıcı yaratıcılık) }\end{array}$ \\
\hline 28 & $\begin{array}{l}\text { interpretative } \\
\text { tradition } \\
144\end{array}$ & $\begin{array}{l}\text { yorumsal } \\
\text { gelenek } \\
172\end{array}$ & & $\begin{array}{l}\text { Çeviride kullanılan karşılık uygun } \\
\text { görülmektedir ancak terim standart } \\
\text { değildir. Türkçedeki terim açığını } \\
\text { gidermek için tamamlayıcı bir } \\
\text { yaratıcılık gösterilmiştir. Dolayısıyla, }\end{array}$ \\
\hline
\end{tabular}




\begin{tabular}{|c|c|c|c|}
\hline & & & $\begin{array}{l}\text { terim için, "tam gereksinim" } \\
\text { durumunda üretilmiş kabul } \\
\text { edilebilir bir terim önerisi olduğu } \\
\text { söylenebilir. (birincil gereksinim- } \\
\text { tamamlayıcı yaratıcılık) }\end{array}$ \\
\hline 29 & $\begin{array}{l}\text { lexical system } \\
68\end{array}$ & $\begin{array}{l}\text { sözlükbirims } \\
\text { el sistem } \\
89\end{array}$ & $\begin{array}{l}\text { Terim literatürde yerleşik değildir. } \\
\text { Dolayısı ile yeni terim gereksinimine } \\
\text { açık olduğu düşünülebilir. (ikincil } \\
\text { gereksinim-gerekli yaratıcılık) }\end{array}$ \\
\hline 30 & $\begin{array}{l}\text { liminal } \\
\text { author/ } \\
\text { the author on } \\
\text { the threshold } \\
69\end{array}$ & $\begin{array}{l}\text { eşik } \\
\text { yazar/eşikte } \\
\text { ki yazar } \\
90\end{array}$ & $\begin{array}{l}\text { Öztürk Kasar'ın "eşik özne" } \\
\text { teriminden hareketle "eşik yazar" } \\
\text { karşılığı kabul edilebilir bir çeviri } \\
\text { olup, özgün terim Eco'nun doktora } \\
\text { öğrencisi Mauro Ferraresi'ye aittir. } \\
\text { Çeviride kullanılan karşılık uygun } \\
\text { görülmektedir ancak terim standart } \\
\text { değildir. Türkçedeki terim açığını } \\
\text { gidermek için tamamlayıcı bir } \\
\text { yaratıcılık gösterilmiştir. Dolayısıyla, } \\
\text { terim için, "tam gereksinim" } \\
\text { durumunda üretilmiş kabul } \\
\text { edilebilir bir terim önerisi olduğu } \\
\text { söylenebilir. (birincil gereksinim- } \\
\text { tamamlayıcı yaratıcılık) }\end{array}$ \\
\hline 31 & $\begin{array}{l}\text { linguistic } \\
\text { expression } \\
69\end{array}$ & $\begin{array}{l}\text { dilsel ifade } \\
90\end{array}$ & $\begin{array}{l}\text { Çevirmenin Türkçeye aktardığı } \\
\text { terim literatürde yerleşiktir ve } \\
\text { kullanılmaktadır. (sıfır gereksinim- } \\
\text { sıfır yaratıcılık) }\end{array}$ \\
\hline 32 & $\begin{array}{l}\text { linguistic } \\
\text { intention } \\
69\end{array}$ & $\begin{array}{l}\text { dilsel niyet } \\
90\end{array}$ & $\begin{array}{l}\text { Çevirmenin Türkçeye aktardığı } \\
\text { terim literatürde yerleşiktir ve } \\
\text { kullanılmaktadır. (sıfır gereksinim- } \\
\text { sıfır yaratıcılık) }\end{array}$ \\
\hline 33 & $\begin{array}{l}\text { linguistic } \\
\text { means } \\
72\end{array}$ & $\begin{array}{l}\text { dilsel } \\
\text { araçlar } \\
93\end{array}$ & $\begin{array}{l}\text { Çeviride kullanılan karşılık uygun } \\
\text { görülmektedir ancak terim standart } \\
\text { değildir. Türkçedeki terim açığını } \\
\text { gidermek için tamamlayıcı bir } \\
\text { yaratıcılık gösterilmiştir. Dolayısıyla, } \\
\text { terim için, "tam gereksinim" } \\
\text { durumunda üretilmiş kabul } \\
\text { edilebilir bir terim önerisi olduğu } \\
\text { söylenebilir. (birincil gereksinim- } \\
\text { tamamlayıcı yaratıcılık) }\end{array}$ \\
\hline 34 & $\begin{array}{l}\text { model author } \\
64\end{array}$ & $\begin{array}{l}\text { örnek yazar } \\
84\end{array}$ & $\begin{array}{l}\text { Çevirmenin Türkçeye aktardığı } \\
\text { terim literatürde yerleşiktir ve } \\
\text { kullanılımaktadır. (sıfır gereksinim- } \\
\text { sıfır yaratıcılık) }\end{array}$ \\
\hline
\end{tabular}


Terimbilim Odağında ve Çevirmenin Tanıklığında Kuramsal Çeviri

\begin{tabular}{|c|c|c|c|c|}
\hline 35 & $\begin{array}{l}\text { model reader } \\
64\end{array}$ & $\begin{array}{l}\text { örnek okur } \\
84\end{array}$ & & $\begin{array}{l}\text { Çevirmenin Türkçeye aktardığı } \\
\text { terim literatürde yerleşiktir ve } \\
\text { kullanılmaktadır. (sıfır gereksinim- } \\
\text { sıfır yaratıcılık) }\end{array}$ \\
\hline 36 & $\begin{array}{l}\text { morphological } \\
\text { resemblance } \\
45\end{array}$ & $\begin{array}{l}\text { morfolojik } \\
\text { benzerlik } \\
63\end{array}$ & & $\begin{array}{l}\text { Terim literatürde yerleşik değildir. } \\
\text { Dolayısı ile yeni terim gereksinimine } \\
\text { açık olduğu düşünülebilir. (ikincil } \\
\text { gereksinim-gerekli yaratıcılık) }\end{array}$ \\
\hline 37 & $\begin{array}{l}\text { original } \\
\text { message } \\
42\end{array}$ & $\begin{array}{l}\text { özgün ileti } \\
61\end{array}$ & & $\begin{array}{l}\text { Çevirmenin Türkçeye aktardığı } \\
\text { terim literatürde yerleşiktir ve } \\
\text { kullanılmaktadır. (sıfır gereksinim- } \\
\text { sıfır yaratıcılık) }\end{array}$ \\
\hline 38 & $\begin{array}{l}\text { overinterpret } \\
\text { ation } \\
48\end{array}$ & $\begin{array}{l}\text { aşırı yorum } \\
66\end{array}$ & & $\begin{array}{l}\text { Çeviride kullanılan karşılık uygun } \\
\text { görülmektedir. Türkçedeki terim } \\
\text { açığını gidermek için tamamlayıcı } \\
\text { bir yaratıcılık gösterilmiştir. } \\
\text { Dolayısıyla, terim için, "tam } \\
\text { gereksinim" durumunda üretilmiş } \\
\text { kabul edilebilir bir terim önerisi } \\
\text { olduğu söylenebilir. (birincil } \\
\text { gereksinim-tamamlayıcı yaratıcılık) }\end{array}$ \\
\hline 39 & $\begin{array}{l}\text { performance } \\
\text { of language } \\
68\end{array}$ & $\begin{array}{l}\text { dil edimi } \\
88\end{array}$ & & $\begin{array}{l}\text { Çevirmenin Türkçeye aktardığı } \\
\text { terim literatürde yerleşiktir ve } \\
\text { kullanılmaktadır. (sıfır gereksinim- } \\
\text { sıfır yaratıcılık) }\end{array}$ \\
\hline 40 & $\begin{array}{l}\text { philological } \\
\text { analysis } \\
69\end{array}$ & $\begin{array}{l}\text { filolojik } \\
\text { çözümleme } \\
89\end{array}$ & & $\begin{array}{l}\text { Çevirmenin Türkçeye aktardığı } \\
\text { terim literatürde yerleşiktir ve } \\
\text { kullanılmaktadır. (sıfır gereksinim- } \\
\text { sıfır yaratıcılık) }\end{array}$ \\
\hline 41 & $\begin{array}{l}\text { poetic code } \\
42\end{array}$ & $\begin{array}{l}\text { şiirsel kod } \\
61\end{array}$ & $\begin{array}{l}\text { poetic } \\
\text { function=yazıns } \\
\text { al işlev } \\
\text { (İmer vd.) } \\
\text { poetic } \\
\text { function=yazın } \\
\text { işlevi, yazınsal } \\
\text { işlev }\end{array}$ & $\begin{array}{l}\text { Terim literatürde yerleşik değildir. } \\
\text { Dolayısı ile yeni terim gereksinimine } \\
\text { açık olduğu düşünülebilir. (ikincil } \\
\text { gereksinim-gerekli yaratıcılık) }\end{array}$ \\
\hline 42 & $\begin{array}{l}\text { postulated } \\
\text { model } \\
\text { reader } \\
65\end{array}$ & $\begin{array}{l}\text { çağrıştırılan } \\
\text { ya da } \\
\text { varsayılan } \\
\text { okur } \\
85\end{array}$ & & $\begin{array}{l}\text { Terim literatürde yerleşik değildir. } \\
\text { Dolayısı ile yeni terim gereksinimine } \\
\text { açık olduğu düşünülebilir. (ikincil } \\
\text { gereksinim-gerekli yaratıcılık) }\end{array}$ \\
\hline 43 & $\begin{array}{l}\text { proportional } \\
\text { analogy } \\
45\end{array}$ & $\begin{array}{l}\text { oransal } \\
\text { analoji } \\
63\end{array}$ & & $\begin{array}{l}\text { Terim literatürde yerleşik değildir. } \\
\text { Dolayısı ile yeni terim gereksinimine } \\
\text { açık olduğu düşünülebilir. (ikincil } \\
\text { gereksinim-gerekli yaratıcılık) }\end{array}$ \\
\hline
\end{tabular}




\begin{tabular}{|c|c|c|c|c|}
\hline 44 & $\begin{array}{l}\text { reader- } \\
\text { oriented } \\
\text { theory } \\
43\end{array}$ & $\begin{array}{l}\text { okur } \\
\text { yönelimli } \\
\text { kuram } \\
62\end{array}$ & & $\begin{array}{l}\text { Terim literatürde yerleşik değildir. } \\
\text { Dolayısı ile yeni terim gereksinimine } \\
\text { açık olduğu düşünülebilir. (ikincil } \\
\text { gereksinim-gerekli yaratıcılık) }\end{array}$ \\
\hline 45 & $\begin{array}{l}\text { real reader } \\
40\end{array}$ & $\begin{array}{l}\text { gerçek okur } \\
58\end{array}$ & & $\begin{array}{l}\text { Çeviride kullanılan karşılık uygun } \\
\text { görülmektedir ancak terim standart } \\
\text { değildir. Türkçedeki terim açığını } \\
\text { gidermek için tamamlayıcı bir } \\
\text { yaratıcılık gösterilmiştir. Dolayısıyla, } \\
\text { terim için, "tam gereksinim" } \\
\text { durumunda üretilmiş kabul } \\
\text { edilebilir bir terim önerisi olduğu } \\
\text { söylenebilir. (birincil gereksinim- } \\
\text { tamamlayıcı yaratıcılık) }\end{array}$ \\
\hline 46 & $\begin{array}{l}\text { referential } \\
\text { power } \\
42\end{array}$ & $\begin{array}{l}\text { göndergesel } \\
\text { güç } \\
61\end{array}$ & $\begin{array}{l}\text { referential } \\
\text { terimi için İmer } \\
\text { gönderimsel } \\
\text { terimini } \\
\text { önermektedir. } \\
\text { referential } \\
\text { equivalence için } \\
\text { ise (Rifat vd) } \\
\text { göndergesel } \\
\text { eşdeğerlik } \\
\text { terimini } \\
\text { önermektedir. } \\
\end{array}$ & $\begin{array}{l}\text { Rifat vd'nin 'göndergesel } \\
\text { eşdeğerlik' kullanımından hareketle } \\
\text { çevirmenin önerdiği kavram } \\
\text { kullanılabilir. Dolayısıyla, terim için, } \\
\text { "tam gereksinim" durumunda } \\
\text { üretilmiş kabul edilebilir bir terim } \\
\text { önerisi olduğu söylenebilir. (birincil } \\
\text { gereksinim-tamamlayıcı yaratıcılık) }\end{array}$ \\
\hline 47 & $\begin{array}{l}\text { rights of the } \\
\text { text } \\
84\end{array}$ & $\begin{array}{l}\text { metnin } \\
\text { hakları } \\
106\end{array}$ & & $\begin{array}{l}\text { Çeviride kullanılan karşılık uygun } \\
\text { görülmektedir ancak terim standart } \\
\text { değildir. Türkçedeki terim açığını } \\
\text { gidermek için tamamlayıcı bir } \\
\text { yaratıcılık gösterilmiştir. Dolayısıyla, } \\
\text { terim için, "tam gereksinim" } \\
\text { durumunda üretilmiş kabul } \\
\text { edilebilir bir terim önerisi olduğu } \\
\text { söylenebilir. (birincil gereksinim- } \\
\text { tamamlayıcı yaratıcılık) }\end{array}$ \\
\hline 48 & $\begin{array}{l}\text { sane } \\
\text { interpretation } \\
48\end{array}$ & $\begin{array}{l}\text { sağlıklı } \\
\text { yorum } \\
67\end{array}$ & & $\begin{array}{l}\text { Çeviride kullanılan karşılık uygun } \\
\text { görülmektedir ancak terim standart } \\
\text { değildir. Türkçedeki terim açığını } \\
\text { gidermek için tamamlayıcı bir } \\
\text { yaratıcılık gösterilmiştir. Dolayısıyla, } \\
\text { terim için, "tam gereksinim" } \\
\text { durumunda üretilmiş kabul } \\
\text { edilebilir bir terim önerisi olduğu } \\
\text { söylenebilir. (birincil gereksinim- } \\
\text { tamamlayıcı yaratıcılık) }\end{array}$ \\
\hline
\end{tabular}




\begin{tabular}{|c|c|c|c|}
\hline 49 & $\begin{array}{l}\text { semantic } \\
\text { association } \\
80\end{array}$ & $\begin{array}{l}\text { anlamsal } \\
\text { çağrışım } \\
102\end{array}$ & $\begin{array}{l}\text { Çeviride kullanılan karşılık uygun } \\
\text { görülmektedir ancak terim standart } \\
\text { değildir. Türkçedeki terim açı̆̆ını } \\
\text { gidermek için tamamlayıcı bir } \\
\text { yaratıcılık gösterilmiştir. Dolayısıyla, } \\
\text { terim için, "tam gereksinim" } \\
\text { durumunda üretilmiş kabul } \\
\text { edilebilir bir terim önerisi olduğu } \\
\text { söylenebilir. (birincil gereksinim- } \\
\text { tamamlayıcı yaratıcılık) }\end{array}$ \\
\hline 50 & $\begin{array}{l}\text { semantic } \\
\text { isotopy } \\
62\end{array}$ & $\begin{array}{l}\text { semantik } \\
\text { izotopi } \\
82\end{array}$ & $\begin{array}{l}\text { Terim literatürde yerleşik değildir. } \\
\text { Dolayısı ile yeni terim gereksinimine } \\
\text { açık olduğu düşünülebilir. (ikincil } \\
\text { gereksinim-gerekli yaratıcılık) }\end{array}$ \\
\hline 51 & $\begin{array}{l}\text { semiotic } \\
\text { analysis } \\
48\end{array}$ & $\begin{array}{l}\text { göstergebili } \\
\text { msel } \\
\text { çözümleme } \\
66\end{array}$ & $\begin{array}{l}\text { Çevirmenin Türkçeye aktardığı } \\
\text { terim literatürde yerleşiktir ve } \\
\text { kullanılmaktadır.(sıfır gereksinim- } \\
\text { sıfır yaratıcılık) }\end{array}$ \\
\hline 52 & $\begin{array}{l}\text { semiotic } \\
\text { means } \\
147\end{array}$ & $\begin{array}{l}\text { göstergebili } \\
\text { msel araç } \\
176\end{array}$ & $\begin{array}{l}\text { Çeviride kullanılan karşılık uygun } \\
\text { görülmektedir ancak terim standart } \\
\text { değildir. Türkçedeki terim açığını } \\
\text { gidermek için tamamlayıcı bir } \\
\text { yaratıcılık gösterilmiştir. Dolayısıyla, } \\
\text { terim için, "tam gereksinim" } \\
\text { durumunda üretilmiş kabul } \\
\text { edilebilir bir terim önerisi olduğu } \\
\text { söylenebilir. (birincil gereksinim- } \\
\text { tamamlayıcı yaratııılık) }\end{array}$ \\
\hline 53 & $\begin{array}{l}\text { semantic } \\
\text { relationships } \\
70\end{array}$ & $\begin{array}{l}\text { semantik } \\
\text { ilişkiler } \\
90\end{array}$ & $\begin{array}{l}\text { Terim literatürde yerleşik değildir. } \\
\text { Dolayısı ile yeni terim gereksinimine } \\
\text { açık olduğu düşünülebilir. (ikincil } \\
\text { gereksinim-gerekli yaratıcılık) }\end{array}$ \\
\hline 54 & $\begin{array}{l}\text { semiotic } \\
\text { strategy } \\
64\end{array}$ & $\begin{array}{l}\text { göstergebili } \\
\text { msel strateji } \\
85\end{array}$ & $\begin{array}{l}\text { Terim literatürde yerleşik değildir. } \\
\text { Dolayısı ile yeni terim gereksinimine } \\
\text { açık olduğu düşünülebilir. (ikincil } \\
\text { gereksinim-gerekli yaratıcılık) }\end{array}$ \\
\hline 55 & $\begin{array}{l}\text { signification } \\
\text { by } \\
\text { ostension } \\
47\end{array}$ & $\begin{array}{l}\text { sunum } \\
\text { yoluyla } \\
\text { imleme } \\
65\end{array}$ & $\begin{array}{l}\text { Terim literatürde yerleşik değildir. } \\
\text { Dolayısı ile yeni terim gereksinimine } \\
\text { açık olduğu düşünülebilir. (ikincil } \\
\text { gereksinim-gerekli yaratıcılık) }\end{array}$ \\
\hline 56 & $\begin{array}{l}\text { signification } \\
\text { system } \\
64\end{array}$ & $\begin{array}{l}\text { anlam } \\
\text { sistemi } \\
84\end{array}$ & $\begin{array}{l}\text { Terim literatürde yerleşik değildir. } \\
\text { Dolayısı ile yeni terim gereksinimine } \\
\text { açık olduğu düşünülebilir. (ikincil } \\
\text { gereksinim-gerekli yaratıcılık) }\end{array}$ \\
\hline 57 & $\begin{array}{l}\text { similarity of } \\
\text { name } \\
46\end{array}$ & $\begin{array}{l}\text { ad } \\
\text { benzerliği } \\
64\end{array}$ & $\begin{array}{l}\text { Türkçedeki terim açığını gidermek } \\
\text { için tamamlayıcı bir yaratıcılık } \\
\text { gösterilmiştir. Dolayısıyla, terim }\end{array}$ \\
\hline
\end{tabular}




\begin{tabular}{|c|c|c|c|}
\hline & & & $\begin{array}{l}\text { için, "tam gereksinim" durumunda } \\
\text { üretilmiş kabul edilebilir bir terim } \\
\text { önerisi olduğu söylenebilir. (birincil } \\
\text { gereksinim-tamamlayıcı yaratıcılık) }\end{array}$ \\
\hline 58 & $\begin{array}{l}\text { smart } \\
\text { reader } \\
82\end{array}$ & $\begin{array}{l}\text { keskin } \\
\text { kavrayışlı } \\
\text { okur } \\
103\end{array}$ & $\begin{array}{l}\text { Türkçedeki terim açığını gidermek } \\
\text { için tamamlayıcı bir yaratıcılık } \\
\text { gösterilmiştir. Dolayısıyla, terim } \\
\text { için, "tam gereksinim" durumunda } \\
\text { üretilmiş kabul edilebilir bir terim } \\
\text { önerisi olduğu söylenebilir. (birincil } \\
\text { gereksinim-tamamlayıcı yaratıcılık) }\end{array}$ \\
\hline 59 & $\begin{array}{l}\text { social } \\
\text { treasury } \\
68\end{array}$ & $\begin{array}{l}\text { toplumsal } \\
\text { dağar } \\
88\end{array}$ & $\begin{array}{l}\text { Türkçedeki terim açığını gidermek } \\
\text { için tamamlayıcı bir yaratıcılık } \\
\text { gösterilerek çevirmen tarafından } \\
\text { güzel bir kullanım örneği } \\
\text { sunulmuştur. Türkçede henüz } \\
\text { karşılığı olmayan bu terim için "tam } \\
\text { gereksinim" durumunda üretilmiş } \\
\text { kabul edilebilir bir terim önerisi } \\
\text { olduğu söylenebilir. (birincil } \\
\text { gereksinim-tamamlayıcı yaratıcılık) }\end{array}$ \\
\hline 60 & $\begin{array}{l}\text { stylistic } \\
\text { conventions } \\
65\end{array}$ & $\begin{array}{l}\text { üslup } \\
\text { gelenekleri } \\
85\end{array}$ & $\begin{array}{l}\text { Terim literatürde yerleşik değildir. } \\
\text { Dolayısı ile yeni terim gereksinimine } \\
\text { açık olduğu düşünülebilir. (ikincil } \\
\text { gereksinim-gerekli yaratıcılık) }\end{array}$ \\
\hline 61 & $\begin{array}{l}\text { subject of } \\
\text { utterence } \\
66\end{array}$ & $\begin{array}{l}\text { sözce } \\
\text { öznesi } \\
86\end{array}$ & $\begin{array}{l}\text { Türkçedeki terim açığını gidermek } \\
\text { için tamamlayıcı bir yaratıcılık } \\
\text { gösterilmiştir. Dolayısıyla, terim } \\
\text { için, "tam gereksinim" durumunda } \\
\text { üretilmiş kabul edilebilir bir terim } \\
\text { önerisi olduğu söylenebilir. (birincil } \\
\text { gereksinim-tamamlayıcı yaratıcılık) }\end{array}$ \\
\hline 62 & $\begin{array}{l}\text { suspicious } \\
\text { interpretation } \\
50\end{array}$ & $\begin{array}{l}\text { kuşkucu } \\
\text { yorum } \\
68\end{array}$ & $\begin{array}{l}\text { Türkçedeki terim açığını gidermek } \\
\text { için tamamlayıcı bir yaratıcılık } \\
\text { gösterilmiştir. Dolayısıyla, terim } \\
\text { için, "tam gereksinim" durumunda } \\
\text { üretilmiş kabul edilebilir bir terim } \\
\text { önerisi olduğu söylenebilir. (birincil } \\
\text { gereksinim-tamamlayıcı yaratıcılık) }\end{array}$ \\
\hline 63 & $\begin{array}{l}\text { textual } \\
\text { coherence } \\
64\end{array}$ & $\begin{array}{l}\text { metinsel } \\
\text { tutarlılık } \\
84\end{array}$ & $\begin{array}{l}\text { Çevirmenin Türkçeye aktardığı } \\
\text { terim literatürde yerleşiktir ve } \\
\text { kullanılmaktadır. (sıfır gereksinim- } \\
\text { sıfır yaratıcılık) }\end{array}$ \\
\hline 64 & $\begin{array}{l}\text { textual } \\
\text { counterpart } \\
85\end{array}$ & $\begin{array}{l}\text { metinsel } \\
\text { karşılık } \\
107\end{array}$ & $\begin{array}{l}\text { Türkçedeki terim açığını gidermek } \\
\text { için tamamlayıcı bir yaratıcılık } \\
\text { gösterilmiştir. Dolayısıyla, terim } \\
\text { için, "tam gereksinim" durumunda }\end{array}$ \\
\hline
\end{tabular}


Terimbilim Odağında ve Çevirmenin Tanıklığında Kuramsal Çeviri

\begin{tabular}{|c|c|c|c|}
\hline & & & $\begin{array}{l}\text { üretilmiş kabul edilebilir bir terim } \\
\text { önerisi olduğu söylenebilir. (birincil } \\
\text { gereksinim-tamamlayıcı yaratıcılık) }\end{array}$ \\
\hline 65 & $\begin{array}{l}\text { textual } \\
\text { interpretation } \\
66\end{array}$ & $\begin{array}{l}\text { metin } \\
\text { yorumu } \\
86\end{array}$ & $\begin{array}{l}\text { Çevirmenin Türkçeye aktardığı } \\
\text { terim literatürde yerleşiktir ve } \\
\text { kullanılmaktadır. (sıfır gereksinim- } \\
\text { sıfır yaratıcılık) }\end{array}$ \\
\hline 66 & $\begin{array}{l}\text { textual } \\
\text { strategy } \\
66\end{array}$ & $\begin{array}{l}\text { metinsel } \\
\text { strateji } \\
86\end{array}$ & $\begin{array}{l}\text { Terim literatürde yerleşik değildir. } \\
\text { Dolayısı ile yeni terim gereksinimine } \\
\text { açık olduğu düşünülebilir. (ikincil } \\
\text { gereksinim-gerekli yaratıcılık) }\end{array}$ \\
\hline 67 & $\begin{array}{l}\text { textual } \\
\text { surface } \\
64\end{array}$ & $\begin{array}{l}\text { metnin } \\
\text { yüzeyi } \\
84\end{array}$ & $\begin{array}{l}\text { Çeviride kullanılan karşılık uygun } \\
\text { görülmektedir ancak terim standart } \\
\text { değildir. Türkçedeki terim açığını } \\
\text { gidermek ç̧in tamamlayıcı bir } \\
\text { yaratıcılık gösterilmiştir. Dolayısıyla, } \\
\text { terim için, "tam gereksinim" } \\
\text { durumunda üretilmiş kabul } \\
\text { edilebilir bir terim önerisi olduğu } \\
\text { söylenebilir. (birincil gereksinim- } \\
\text { tamamlayıcı yaratıcılık) }\end{array}$ \\
\hline 68 & $\begin{array}{l}\text { transcendent } \\
\text { al } \\
\text { meaning } \\
25\end{array}$ & $\begin{array}{l}\text { aşkın anlam } \\
42\end{array}$ & 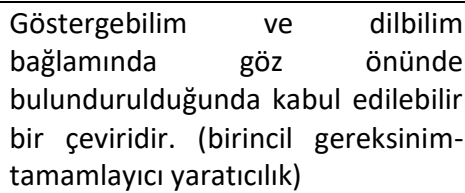 \\
\hline 69 & $\begin{array}{l}\text { transparent } \\
\text { intention } \\
78\end{array}$ & $\begin{array}{l}\text { saydam } \\
\text { niyet } \\
100\end{array}$ & $\begin{array}{l}\text { Türkçedeki terim açığını gidermek } \\
\text { için tamamlayıcı bir yaratıcılık } \\
\text { gösterilmiştir. Dolayısıyla, terim } \\
\text { için, "tam gereksinim" durumunda } \\
\text { üretilmiş kabul edilebilir bir terim } \\
\text { önerisi olduğu söylenebilir. (birincil } \\
\text { gereksinim-tamamlayıcı yaratıcılık) }\end{array}$ \\
\hline 70 & $\begin{array}{l}\text { unattainable } \\
\text { intention } \\
78\end{array}$ & $\begin{array}{l}\text { erişilmez } \\
\text { niyet } \\
99\end{array}$ & $\begin{array}{l}\text { Türkçedeki terim açığını gidermek } \\
\text { için tamamlayıcı bir yaratıcılık } \\
\text { gösterilmiştir. Dolayısıyla, terim } \\
\text { için, "tam gereksinim" durumunda } \\
\text { üretilmiş kabul edilebilir bir terim } \\
\text { önerisi olduğu söylenebilir. (birincil } \\
\text { gereksinim-tamamlayıcı yaratıcılık) }\end{array}$ \\
\hline 71 & $\begin{array}{l}\text { uncommitted } \\
\text { reader } \\
75\end{array}$ & $\begin{array}{l}\text { yansız okur } \\
96\end{array}$ & $\begin{array}{l}\text { Türkçedeki terim açığını gidermek } \\
\text { için tamamlayıcı bir yaratıcılık } \\
\text { gösterilmiştir. Dolayısıyla, terim } \\
\text { için, "tam gereksinim" durumunda } \\
\text { üretilmiş kabul edilebilir bir terim } \\
\text { önerisi olduğu söylenebilir. (birincil } \\
\text { gereksinim-tamamlayıcı yaratıcılık) }\end{array}$ \\
\hline
\end{tabular}




\begin{tabular}{|c|c|c|c|c|}
\hline 72 & $\begin{array}{l}\text { univocal } \\
39\end{array}$ & $\begin{array}{l}\text { tekanlamlı } \\
57\end{array}$ & $\begin{array}{l}\text { Öztürk Kasar \& } \\
\text { Tuna (2017, } \\
\text { s.430)'nın } \\
\text { önerdiği } \\
\text { kavramla tam } \\
\text { örtüşme }\end{array}$ & $\begin{array}{lcc}\text { Öztürk Kasar ve } & \text { Tuna (2017, } \\
\text { 430)'nın önerdiği } & \text { kavramla tam } \\
\text { örtüşme (sıfır } & \text { gereksinim-sıfır } \\
\text { yaratıcılık) } & & \end{array}$ \\
\hline 73 & $\begin{array}{l}\text { unlimited } \\
\text { semiosis } \\
24\end{array}$ & $\begin{array}{l}\text { sınırsız } \\
\text { semiosis } \\
39\end{array}$ & & $\begin{array}{l}\text { Çevirmenin Türkçeye aktardığı } \\
\text { terim literatürde yerleşiktir ve } \\
\text { kullanılmaktadır. (sıfır gereksinim- } \\
\text { sıfır yaratıcılık) }\end{array}$ \\
\hline 74 & $\begin{array}{l}\text { untenable } \\
\text { interpretation } \\
78\end{array}$ & $\begin{array}{l}\text { asılsız } \\
\text { yorum } \\
99\end{array}$ & & $\begin{array}{l}\text { Türkçedeki terim açığını gidermek } \\
\text { için tamamlayıcı bir yaratıcılık } \\
\text { gösterilmiştir. Dolayısıyla, terim } \\
\text { için, "tam gereksinim" durumunda } \\
\text { üretilmiş kabul edilebilir bir terim } \\
\text { önerisi olduğu söylenebilir. (birincil } \\
\text { gereksinim-tamamlayıcı yaratıcılık) }\end{array}$ \\
\hline
\end{tabular}

